M. C. Lillie, C. E. Budd

\title{
DIET ISOTOPE ANALYSIS AND RELATED STUDIES IN PREHISTORIC UKRAINE: FACT, FICTION AND FANTASY
}

This paper outlines the results of twenty-eight years of collaborations between the authors and colleagues in Kiev, initiated when the first author began PhD research at Sheffield University under the supervision of the late Professor Marek Zvelebil in 1992. From the outset of this doctoral research Professor Dmitri Telegin, to whom this paper is dedicated, and Dr. Inna Potekhina, were fundamental not only to the success of the original research programme, but in terms of the considerable generosity, insight and friendship that was extended to the lead author as he navigated his way through the earlier Holocene parts of Ukrainian prehistory. The current study is as much a result of the work of the current authors as it is of collaboration and collegiality of these colleagues.

The topics considered throughout this paper focus around the key observations and themes that have been developed since the research began. It also aims to highlight those areas where inconsistencies occur, and where clarification is deemed warranted due to the activities of researchers who have failed to fully appreciate the nuances of Ukrainian prehistory and multi-disciplinary research agendas. It is apparent that, in light of a recent "gold rush" to claim ownership of the materials available in Ukraine, at prehistoric sites of all periods, there is clearly a need for a considered and careful approach to the data generated from dietary isotope and related studies. Furthermore, our research since the early $1990^{s}$ has shown that misidentification of fragmentary or isolated bone in both primary and secondary contexts can lead to erroneous interpretations and occasional "flights of fancy". This paper will outline a number of the issues identified, and also explore issues around data use and representation in an attempt to offer some balance to discussions of prehistoric diet and chronology in Ukraine.

Keywords: Ukraine, prehistory, dietary isotope analysis, $\delta^{13} \mathrm{C}, \delta^{15} \mathrm{~N}, A M S$ dating, freshwater reservoir effects.

(C) M. C. LILLIE, C. E. BUDD, 2020
Introduction. Studies of diet using stable isotope analysis alongside dental and skeletal pathology can provide detailed insights into the nature of the subsistence strategies employed by prehistoric groups, and their past lifeways. Initial investigations in the $1990^{\mathrm{s}}$, into the dietary pathways of the Dnieper-Donets culture, through analysis of skeletal remains from the Mariupoltype cemeteries, showed that these groups placed an emphasis on the consumption of terrestrial animals and freshwater resources, alongside vegetal foodstuffs (the latter being less well reflected in isotopic studies that use bone collagen - see discussion below). Alongside palaeopathological and osteological studies of the human populations from the Dnieper cemeteries the research agenda has integrated AMS radiocarbon dating in an effort to provide an absolute chronological framework to the cemeteries studied. As discussed below, studies that fail to undertake such analyses run the risk of misinterpretation of the results from parallel studies of diet and pathology, and can, as will be highlighted, produce fundamentally flawed interpretations and misrepresentation of the evidence for past human lifeways.

Our investigations to date have confirmed that across the prehistoric periods, from at least $10,200 \mathrm{cal}$ BC through to ca. $3500 \mathrm{cal} \mathrm{BC}$ (and probably beyond) the consumption of freshwater resources, including species of fish such as carp and pearl roach, formed an integral, and fundamental, part of subsistence strategies in the Dnieper region (Lillie et al. 2011; Potekhina et al. 2014). It has also been possible to demonstrate the existence of a freshwater reservoir effect that is influencing the absolute (radiocarbon) dating of the individuals that are interred in the cemeteries of the Dnieper region, where freshwater 
resources are shown to be integral to subsistence strategies. As such, the available absolute dating of these cemeteries, when undertaken on the human remains themselves, or on freshwater resources, must be considered with caution when discussing the socio-cultural evolution of the populations being studied (Lillie et al. 2009).

Importantly, the continued reliance on the exploitation of wild resources across the Mesolithic and Neolithic period's means that the definition of the Neolithic does not necessarily follow the convention of a shift towards the exploitation of domesticates in many areas of Eastern Europe, as the transition lacks the major socio-economic transformations that generally demarcate the transition from a food extraction to a food production economy (Lillie et al. 2020). Indeed, as previously noted by Dolukhanov and Khotinsky (1984), whilst the appearance of a production economy would normally indicate Neolithisation, other criteria, such as the first appearance of ceramics, improved working tools, new forms of hunting and an increased reliance on fishing are also used to define the transition to a «Neolithic» way of life in Ukraine, and many parts of Eastern Europe (also Motuzaitë Matuzevičiútë, Telizhenko 2016). In addition, Telegin and Titova (1993) attributed all those cultures which are characterised by the presence of ceramics, but lacking metal, to the Neolithic period. Furthermore, it should also be noted that, given the areal extent of the region of study, it is perhaps unsurprising that the nature and timing of this transition displays significant asynchronicity when studied in both a west - east and a south-north direction across Ukraine (Lillie et al. 2020, p. 188).

In general, research into the prehistoric populations of Ukraine has been developed within a rigorous methodological and scientific framework, but on occasion a lack of detailed knowledge and understanding of context has resulted in the publication of ill-conceived or poorly thought out research that has weakened the validity of new studies in this region (see Budd et al. 2020 for an overview of these studies). The current paper seeks to highlight areas where a more rigorous scientific and theoretical basis may be warranted, to consider aspects of recent studies undertaken by researchers who are relatively new to Ukrainian prehistoric studies, and to outline areas that would benefit from a more considered approach, or from clarification of the results obtained; both in terms of context and previous studies (see critiques in Lillie 2020; Lillie et al. 2020).

1. Background. The Dnieper Rapids region of Ukraine contains a wealth of cemeteries and burials dating from the earliest Holocene through to the later prehistoric periods and beyond (Telegin 1986; Telegin, Potekhina 1987; Lillie 1996; 1998a; 1998b). These cemeteries, the Dnieper-Donets Mariupol-type cemeteries (DD M-t), formed the basis of the first authors $\mathrm{PhD}$ research across the $1990^{\text {s }}$, and more recently (over the past decade) has formed an integral element of the second authors' postgraduate and postdoctoral research at Oxford and Umeå Universities. Across this research period a number of reassessments of the chronological development of the cemeteries and the socio-cultural developments in evidence have been undertaken in collaboration (e. g. Potekhina, Telegin 1995; Lillie 1998a; 1998b; 1998c; Telegin et al. 2000; 2002; 2003a; 2003b; Lillie et al. 2009; Budd, Lillie 2020), and an overview of this work is presented in our most recent collaboration (Lillie et al. 2020).

Interpretations into the significance of the concentration of cemeteries at the Dnieper Rapids, and along the Dnieper itself, have reinforced observations relating to the importance of a reliable resource base to earlier Holocene fisher-hunterforagers in a region where the areas away from the river valleys are poorly watered and lack the rich vegetation niches found in the river valleys themselves. Dolukhanov and Khotinskiy (1984, p. 319) have previously argued that Mesolithic groups exploited the fauna of the steppe, forest and tundra zones, with fishing and gathering becoming increasingly important factors in their adaptation to the more differentiated early Holocene landscapes (also Gimbutas 1956). In addition, Lillie (2003a, p. 4) has also suggested that the focus of large-scale cemeteries at the Dnieper Rapids argues for, at least, a seasonal aggregation of population at this location in order to exploit the stable resources, such as freshwater and anadromous fish, along with the plants and fauna of the riparian zone. Such aggregations would obviously offer the opportunity for a wide range of socio-political as well as economical interactions between the various groups in and around the Dnieper and its tributaries, and this aspect of inter-group interactions should not be overlooked.

At the cemeteries in this region the burial inventories themselves, and finds from archaeological sites, provide evidence that reinforces the importance of fishing through the presence of fishing related artefacts such as harpoons, net sinkers, fish-hooks, and fish-tooth necklaces, which are, by their very nature, more likely to be reported (e. g., Telegin 1986; Telegin, Potekhina 1987; Lillie, Richards 2000; O'Connell et al. 2000). The archaeological evidence from Neolithic and Eneolithic sites in the Dnieper region indicates that the range of faunal and freshwater resources available during these periods, as shown by the finds from the Neolithic settlements of Sobachky, Sredny Stog I and Buzky (Telegin, Potekhina 1987), and the Eneolithic site of Dereivka II (Telegin 1986), included a broad range of both wild and also some domesticated species. For the Neolithic period these included aurochs, red and roe deer, wild pig and beaver, alongside domesticates such as cattle, sheep / goat, pig, horse and dog (Dolukhanov 1979; Mallory 1987). In most cases 
however, the evidence does not support the significant integration of domesticated species within a production economy, and instead the data probably suggest increasing trade and exchange between the fisher-hunter-foragers in the Dnieper region and adjacent groups of pastoralists and / or farmers.

Freshwater fish species such as European catfish, perch, roach, rudd, asp and carp, along with European pond terrapin and otter, as well as waterfowl such as mallard, pintail duck, goose, teal and coot are all in evidence at the Eneolithic site of Dereivka (Telegin 1986, p. 84). In addition, freshwater mussel and river snails are also attested. It should be anticipated that a similarly broad range of resources would have been available in earlier periods.

Whilst the archaeological data (e. g. Dolukhanov 1979; Telegin 1986; 1987; Telegin, Potekhina 1987; Kozłowski 1989) attests to the exploitation of a range of faunal and freshwater species, only limited research into palaeopathological analysis or dietary studies were undertaken prior to the work of Jacobs $(1993 ; 1994)$ and Lillie $(1996 ; 1997$; 1998a). Research by Lillie (1996; 1998a), initially aimed at characterising the transition to the Neolithic from the perspective of palaeopathological analysis, soon identified the need for enhanced chronological studies (as discussed above), and integrated stable isotope studies through an initial collaboration with Mike Richards at Oxford University (Lillie, Richards 2000). The studies that have been undertaken since this early stage of the research agenda are summarised below.

2. Dietary Isotope Studies. Since the initial integration of dietary isotope studies into the research agenda a number of papers have sought to expand the dataset through whole cemetery analysis and / or through integrated analysis of materials, whether from human, faunal or fish remains, as they became available (e. g. Lillie et al. 2003; 2011; 2016; Lillie, Jacobs 2006; Lillie, Budd 2011; Potekhina et al. 2014; Budd, Lillie 2020; Budd et al. 2020).

Diet isotope studies have their limitations of course, and as noted in Lillie and Budd (2011, p. 44), there are differences in the $\delta^{13} \mathrm{C}$ values obtained when using the different tissues, for example bone collagen or apatite-carbonate, and consequently it is also important to note that the stable isotope analysis of bone collagen predominantly reflects the protein component of the diet (Krueger, Sullivan 1984; Ambrose, Norr 1993; Tieszen, Fagre 1993; Schulting, Richards 2001). As many plant foodstuffs are difficult to "see» isotopically because the protein levels of unprocessed plants are usually quite low when compared to meat (from fauna and fish), there is an inherent «bias» towards meat proteins when using bone collagen in isotope studies, as opposed to reflecting the diet as a whole (Müldner, Richards 2005 and references therein). However, de- spite the fact that diet isotope studies using bone collagen are not 'whole diet' indicators, stable isotope analysis does provide a direct measure of the nature of past human diet, as the carbon isotope value $\left(\delta^{13} \mathrm{C}\right)$, indicates the amount of marine protein in the diet, as compared to terrestrial protein, and bone collagen analysis also distinguishes between different dietary components, such as $\mathrm{C}_{3}$ and $\mathrm{C}_{4}$ photosynthetic plants and the animals that consumed them (Schwarcz, Schoeninger 1991; Richards 2002). Nitrogen stable isotope ratios $\left(\delta^{15} \mathrm{~N}\right)$ are used to establish the trophic level of an organism in the food web, with $\delta^{15} \mathrm{~N}$ enrichment of c. $3-6 \%$ (e. g. $\Delta^{15} \mathrm{~N}_{\text {diet-body }}$ ) observed as one progresses up the food chain (Schoeninger, DeNiro 1984; Minagawa, Wada 1984; Hedges, Reynard 2007).

Throughout the research programme the samples for diet isotope studies have been processed at the Research Laboratory for Archaeology and the History of Art, University of Oxford. In the initial studies (e. g. Lillie, Richards 2000; Lillie, Jacobs 2006) the collagen was extracted from the human bone samples following the protocol outlined in Richards (1998). In the more recent work (Budd 2015; Lillie et al. 2011, p. 61) the bone collagen was obtained from the skeletal material using a modified version of the "Longin» (1971) extraction method. Samples are subjected to a number of acid and $\mathrm{H}_{2} \mathrm{O}$ (MilliQ) washes and freeze dried. The resulting collagen is then analysed using an automated carbon and nitrogen analyzer and a continuous-flow isotope ratio-monitoring massspectrometer (Carlo Erba carbon and nitrogen elemental analyser coupled to a Europa Geo 20/20 mass-spectrometer). Typical replicate measurement errors are of the order of $\pm 0.2 \%$ for $\delta^{13} \mathrm{C}$ and $\delta^{15} \mathrm{~N}$. Only samples which produced collagen yields with a C:N ratio between 2.9 and 3.6 (DeNiro 1985) were used in the analysis of palaeodiet. The following sections summarise the current situation with regards to the analyses that have been undertaken to date, the most recent updates for which appear in Budd and Lillie (2020), and Budd et al. (2020).

2.1. Epipalaeolithic and Mesolithic Subsistence. The cemeteries and sites analysed in the investigation of earlier Holocene subsistence practices include human remains from Vasilyevka III and II, Marievka and Osipovka, and the Crimean site of Fat'ma Koba. It also includes fauna remains from the Epipalaeolithic sites of Vasilyevka III, Voloshkoe and Vyazivok, and the Mesolithic sites of Fat'ma Koba and Rogalik 2 (fig. 1). Research by Lillie and co-workers e. g. Lillie (2003a), Lillie et al. (2003), Lillie and Jacobs (2006), Lillie et al. (2011) has previously suggested that during the Epipalaeolithic and Mesolithic periods the slightly higher $\delta^{15} \mathrm{~N}$ values at the later Mesolithic site of Vasilyevka II (13.40 \pm $0.65 \%$ (at $1 \sigma))$, when compared to $12.75 \pm 0.61 \%$ from Vasilyevka III, is suggestive of either a 


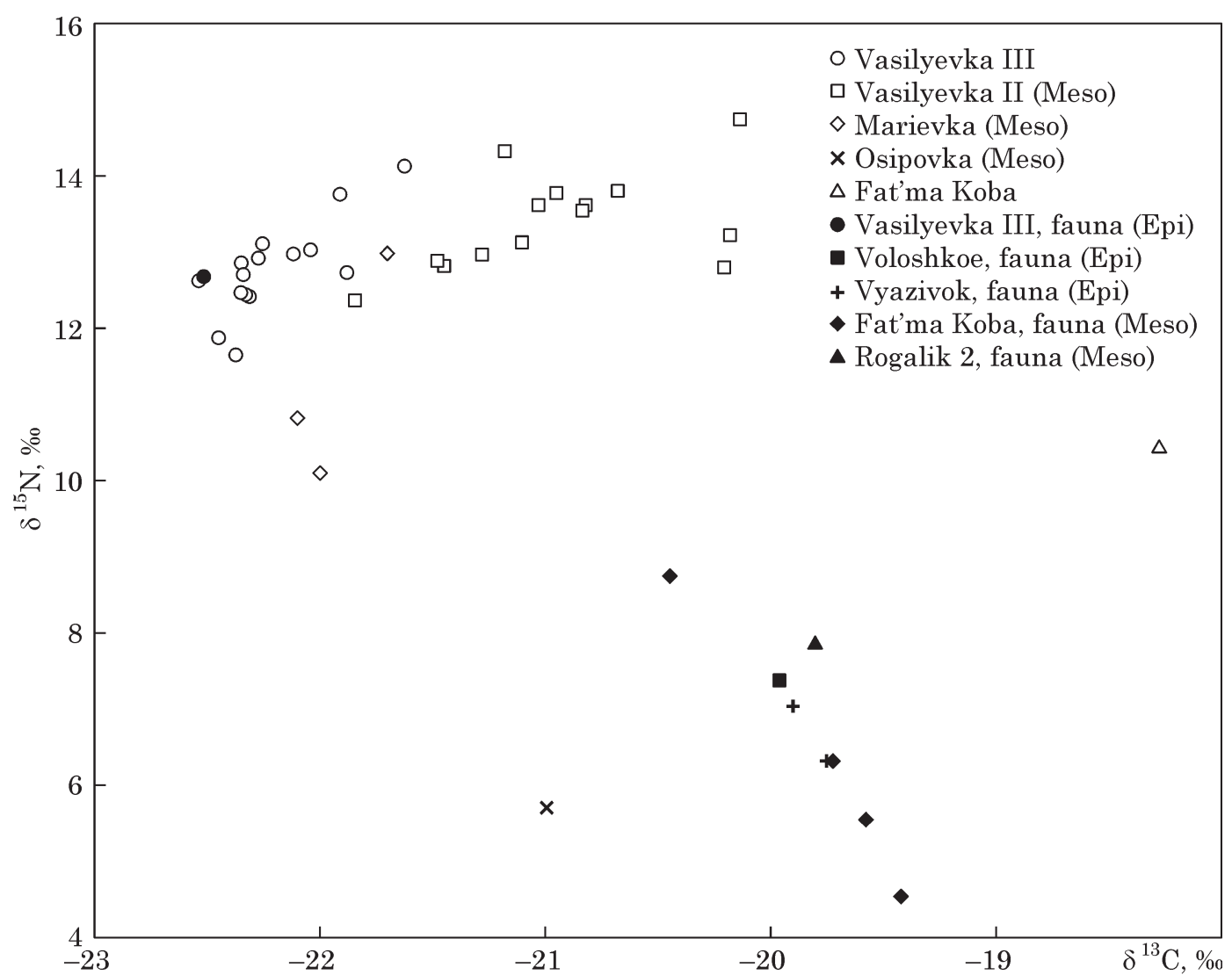

Fig. 1. Human and faunal $\delta^{13} \mathrm{C}$ and $\delta^{15} \mathrm{~N}$ values for the Epipalaeolithic and Mesolithic cemeteries in the study region (after Budd, Lillie 2020)

higher input from freshwater resources in the later Mesolithic period, or alternatively, the exploitation of differing fish species from a range of trophic levels in the riverine ecosystem (Lillie et al. 2011, p. 63). In addition, the $\delta^{13} \mathrm{C}$ values at Vasilyevka II (-20.94 $\pm 0.51 \%$ ) are depleted by $2 \%$ when compared to Vasilyevka III (-22.22 \pm $0.24 \%$; ibid. 2011 , p. $61-63$ ). Importantly, one individual of Mesolithic date from the predominantly Neolithic cemetery of Dereivka I, individual 84 , also exhibits $\delta^{13} \mathrm{C}$ and $\delta^{15} \mathrm{~N}$ values that are fully commensurate with the mainstream values evident through the Epipalaeolithic and Mesolithic periods at $(-23.6 \%$ and $11.4 \%$, although it is noted that the $\delta^{15} \mathrm{~N}$ value is towards the lower end of the ranges reported.

In this context, the data has shown that at the site of Marievka burials 4 and 14 have $\delta^{15} \mathrm{~N}$ ratios that would be commensurate with a diet wherein the majority of dietary proteins are obtained from terrestrial as opposed to freshwater resources. As noted by Budd and Lillie (2020, p. 291) on the basis of the dating at Marievka, these two individuals represent the chronologically earliest evidence for the exploitation of terrestrial as opposed to aquatic dominated diets. Unfortunately due to the limited number of interments at Marievka, and the state of preservation, the analysis by Lillie $(1998 \mathrm{a} ; 2020)$ was only able to produce tentative sex / age determinations of M? aged 50-60 for individual 4 and an indeterminate adult aged
$35-45$ designation for individual 14 , so at this stage in the research agenda there is little value in attempting to establish why the diet of these particular individuals differed when compared to all other individuals studied from the Epipalaeolithic to Mesolithic periods.

It should also be noted that at Fat'ma Koba in Crimea, $\delta^{13} \mathrm{C}$ and $\delta^{15} \mathrm{~N}$ values of $-18.3 \%$ and $10.5 \%$ respectively, for human remains recovered from Layer 4 (which is of either Murzak-Koba or Kukrek culture periodisation; Budd, Lillie 2020, p. 292), has also been interpreted as representing a diet wherein the majority of the dietary proteins are obtained from terrestrial resources. The $\delta^{13} \mathrm{C}$ of $-18.3 \%$ has been suggested as indicating the limited inclusion of some $\mathrm{C}_{4}$ resources at this location, due to the fact that at the time this individual would have been exploiting the environment (ca. 9000-7500 BP) Crimea was a peninsula in a freshwater context within an arid steppe environment (ibid. 2002, p. 292).

There are additional individuals of Mesolithic date from the cemeteries of Dereivka I (Individual 84 - discussed above) and Osipovka (Individual 20b). As noted above, the values for the individual from Dereivka I are towards to lower end of the range identified, being closer to the terrestrial dominated baseline than the majority of the individuals analysed for the Mesolithic. At $6361-5879$ cal BC (OxA-6161; $7270 \pm 110 \mathrm{BP})$ this individual is placed, chronologically, to- 


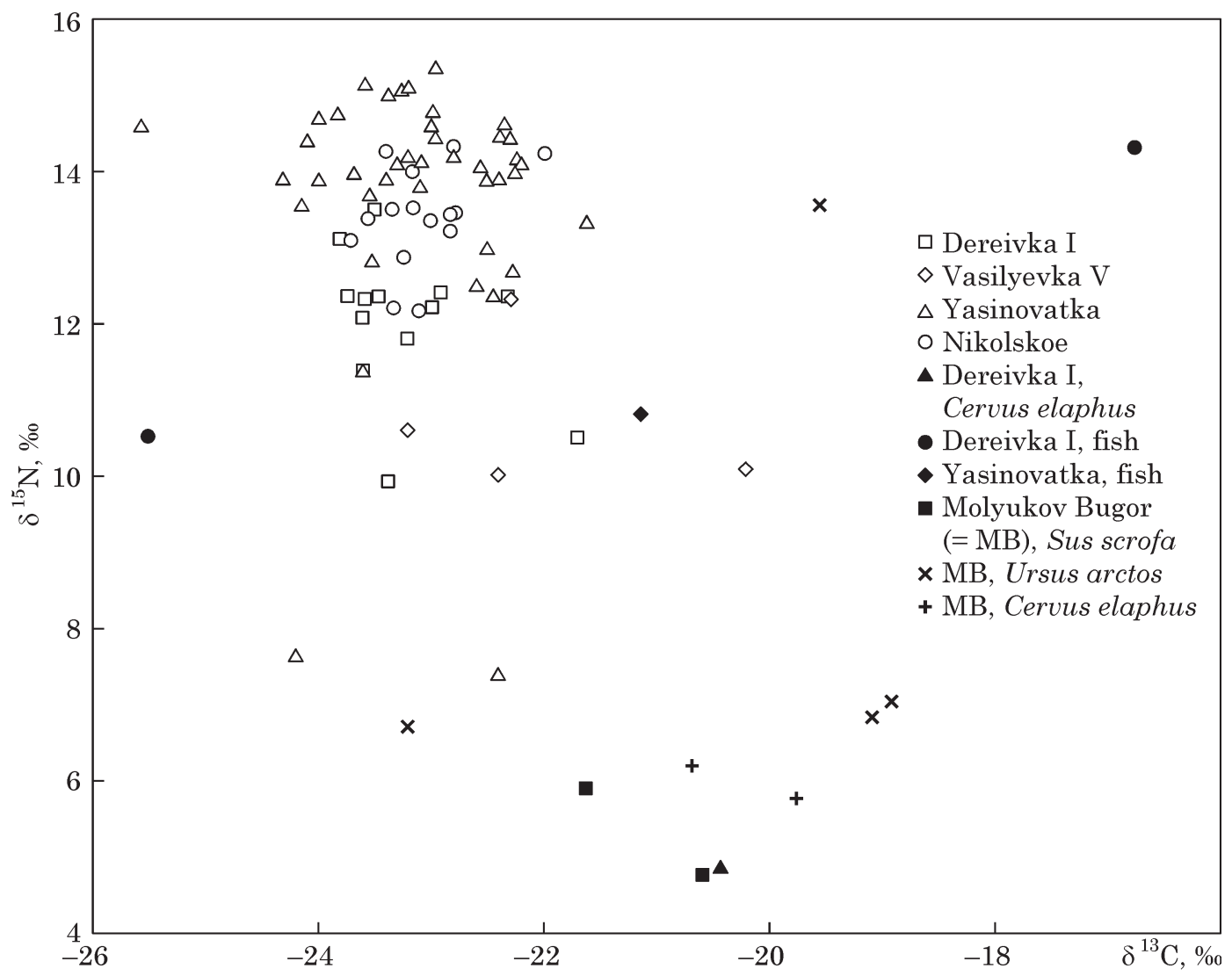

Fig. 2. Human and faunal $\delta^{13} \mathrm{C}$ and $\delta^{15} \mathrm{~N}$ values for the Neolithic cemeteries in the study region (after Budd, Lillie 2020)

wards the end of the Mesolithic period. Unfortunately the individual from Osipovka produced isotope ratios that must be considered anomalous at this stage of the analysis (as they are well below the entire dataset for this period to date) with values of $21.0 \%$ for $\delta^{13} \mathrm{C}$ and $5.7 \%$ for $\delta^{15} \mathrm{~N}$. Given that the material from this individual comprised fragmentary post cranial skeletal elements the possibility that this represents a fauna value as opposed to a human diet isotope value cannot be discounted with certainty, and without assessment using a technique such as ZooMs (Zooarchaeology by Mass Spectrometry) to establish species identification (Buckley et al. 2009), this value is currently discounted from discussions of Mesolithic dietary pathways.

2.2. Neolithic Subsistence. During the Neolithic period there is a continued reliance on freshwater resources, to the point where these dominate the diet at certain locations (fig. 2), although variability in consumption is again in evidence. The data have demonstrated that, at certain locations, there are individuals who have nitrogen ratios that are indicative of a reliance on terrestrial resources, as opposed to the predominant dietary pathways wherein a reliance on freshwater resources is attested.

In this context, as can be seen from fig. 2, two individuals from the cemetery of Dereivka I have $\delta^{13} \mathrm{C}$ values of $23.4 \%$ and $21.7 \%$, and $\delta^{15} \mathrm{~N}$ values of $9.9 \%$ and $10.5 \%$ respectively (individu- als 49 and 33). In addition, individual 93 from Dereivka I has a similarly low nitrogen value at $9.54 \%$ and a carbon value of $26.78 \%$, the latter value is very depleted but it is consistent with the faunal and fish values that have been obtained from this region. Other individuals at this location have nitrogen values that, whilst towards the range of diets with a freshwater component in the Dnieper Rapids region in one instance, may well be more terrestrial based in light of the available baseline data for the forest-steppe zone (e. g. individuals 30 and 42). The values for these individuals are $23.61 \%$ and $23.2 \%$ for $\delta^{13} \mathrm{C}$ and $12.07 \%$ and $11.08 \%$ for $\delta^{15} \mathrm{~N}$ respectively.

There are two individuals from Vasilyevka V with $\delta^{15} \mathrm{~N}$ values of $10.0 \%$ and $10.1 \%$, and a third individual who is elevated slightly at $10.6 \%$ (Individuals 8, 29 and 10), which would indicate the consumption of terrestrial based diets. Overall, it does appear that in general, $\delta^{15} \mathrm{~N}$ values around ca. $11 \%$ and below are indicative of diets that were weighted more towards terrestrial than aquatic resources.

Of some considerable interest in terms of the dietary $\delta^{15} \mathrm{~N}$ values that are recorded, are that two individuals from the cemetery of Yasinovatka (fig. 2) appear to have $\delta^{13} \mathrm{C}$ and $\delta^{15} \mathrm{~N}$ that would appear to indicate divergent dietary pathways to the majority of this population (Budd et al. 2020).

It is worth noting that an additional individual 26, at Yasinovatka also produced a low $\delta^{15} \mathrm{~N}$ 


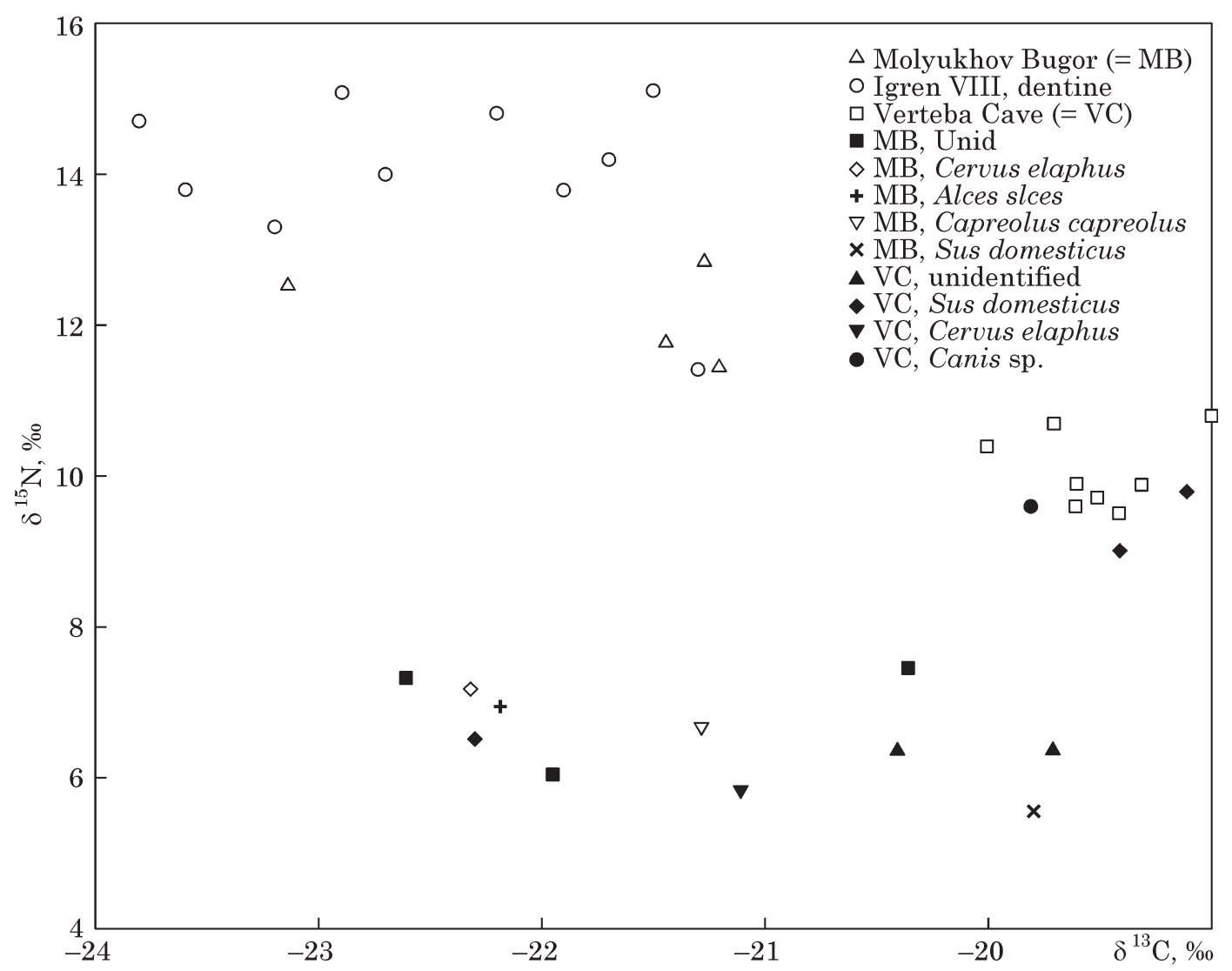

Fig. 3. Human and faunal $\delta^{13} \mathrm{C}$ and $\delta^{15} \mathrm{~N}$ values for the Eneolithic cemeteries in the study region (after Budd, Lillie 2020)

value at $7.6 \%$, but this individual was out of the acceptable range for $\mathrm{C}: \mathrm{N}$ at 4.6, and as such, until further analysis (e. g. re-analysis for diet isotopes and ZooMs) can be undertaken, this individual is also discounted from further consideration.

Overall, whilst there is clear evidence to support variability in dietary pathways during the Neolithic (and preceding Mesolithic) period, it is apparent that that we need a considerable degree of caution in accepting that all samples analysed are in fact human, especially in the case of fragmentary material, or, as suggested by the current research, when the available fauna values indicate that human nitrogen values below ca. $4-$ 5 ppm may suggest misidentification of fragmentary skeletal materials.

2.3. Eneolithic Subsistence. During the Eneolithic period the fact that a number of culture groups are available for study affords insights into differing food procurement strategies, whilst also highlighting the significant dietary differences that occur between groups following agropastoral as opposed to mixed hunting, fishing and foraging food procurement pathways (fig. 3).

The data obtained from Igren 8 and Molukhov Bugor are clearly very distinct, isotopically, when compared to Verteba Cave (fig. 3). Of course, the fact that Verteba Cave is in western Ukraine, as opposed to the Dnieper region, will exert an influence on the isotope ratios in evidence, as will the fact that the individuals from Verteba are pre- sumed to be Trypillia culture farmers. This culture, whilst having evidence to support the fact that varied subsistence regimes were practiced (e. g. Cuik 2008 and references therein), were essentially agro-pastoralists (see discussion below).

The data from the Eneolithic phase at Igren VIII, which is dated to ca. $4337-4074$ cal BC, were originally analysed by Rowena Henderson using high-resolution, incremental isotope analysis of the dentine in order to assess the relative contribution of dietary proteins (Henderson 2015; Lillie et al. 2016). The $\delta^{13} \mathrm{C}$ and $\delta^{15} \mathrm{~N}$ values from Igren VIII are the post-weaning diet signal at 12 years of age for the ten individuals studied. These values, at $22.48 \pm 0.9 \%$ and $14.02 \pm 1.1 \%$ respectively, clearly indicate the significant consumption of freshwater aquatic proteins, such as fish and molluscs (Budd, Lillie 2020). By contrast, the data from the chronologically later site of Molukhov Bugor, at ca. 3951-3705 cal BC, exhibit carbon and nitrogen isotope values for the human inhabitants at $\delta^{13} \mathrm{C}=21.8 \pm 0.9 \%$ and $\delta^{15} \mathrm{~N}=12.2 \pm 0.7 \%$, which, whilst indicative of the continued importance of aquatic proteins well into the Eneolithic period, are suggestive of more diversified subsistence strategies at Molukhov Bugor. As noted by Budd and Lillie (2020, p. 297), the more positive carbon, and lower nitrogen values at Molukhov Bugor probably reflect a mixed subsistence base, where aquatic proteins were 
consumed alongside wild and domestic herbivores, or that there is possibly a difference in the composition of fish species available at the Sula river. By contrast, the data from Igren VIII are indicative of the heavy consumption of freshwater proteins with no isotopic or material culture evidence to suggest the consumption of dietary proteins from the terrestrial landscape in any significant quantity (Telegin, Zaliznyak 1975; Henderson 2015; Lillie et al. 2016; 2020).

3. Radiocarbon dating and the absolute chronology of the Dnieper-Donets Mariupol-type cemeteries. It is an established fact that there is a freshwater radiocarbon reservoir effect (FRE) influencing ${ }^{14} \mathrm{C}$ dating of the Dnieper-Donets Mariupol-type cemeteries (Lillie et al. 2009). However, despite the fact that there is clear evidence for a freshwater radiocarbon reservoir effect in the Dnieper River region, it is nanve to suggest that it is a simple case of calculating a "linear correction factor» using the existing limited dataset alongside $\delta^{15} \mathrm{~N}$ values to account for the ${ }^{14} \mathrm{C}$ offset for these cemeteries (e. g. Kotova 2018).

The freshwater reservoir effect, in oversimplified terms, can cause an anomalous ${ }^{14} \mathrm{C}$ offset in the radiocarbon age of a sample that is either from a freshwater context, or is from a human / animal that has consumed freshwater resources; specifically the effect can produce a ${ }^{14} \mathrm{C}$ age that is artificially "older» than its true radiocarbon age (Ascough et al. 2005; Philippsen 2013).

Radiocarbon dating at three sites in the Dnieper region has revealed a ${ }^{14} \mathrm{C}$ reservoir effect of ca. 100-500 years (see Lillie et al. 2009, p. 62, table 4). At Yasinovatka, there is a chronological offset between the fish tooth sample at $6840 \pm 37$ uncal BP (OxA-17498), and the deer tooth sample at $6121 \pm 34$ uncal BP (OxA-17500), of about 720 years (Lillie et al. 2009, p. 261). This equates to a ca. 250 uncal year difference between the fish sample and the human sample which is dated to $6593 \pm 35$ uncal BP $(\mathrm{OxA}$ 17499), and ca. 470 years between the human sample (with the latter having a ratio of $22.6 \%$ for $\delta^{13} \mathrm{C}$ and $14 \%$ for $\delta^{15} \mathrm{~N}$ ), and the deer sample. By contrast, at Dereivka I, the chronological difference between the fish sample (burial 29) at $6915 \pm 50$ uncal BP (OxA-17501) and the deer sample (square 801 , burial 29) at $6147 \pm 35$ uncal $\mathrm{BP}(\mathrm{OxA}-17594)$ is approximately 770 years. This equates to a disparity of 517 years between the fish and human sample which is dated to $6398 \pm$ 35 uncal BP (OxA-17495), and 251 years between the human and the deer sample. The human sample (individual 29) from Dereivka I has yet to be analysed for diet isotopes, but the range from 12 individuals at this cemetery for $\delta^{15} \mathrm{~N}$ is $9.9 \%$ to $13.05 \%$ o $\left(\delta^{15} \mathrm{~N} 11.96 \pm 0.95 \%\right.$ ).

Given that the Yasinovatka individual has a $\delta^{15} \mathrm{~N}$ value of $14 \%$ and an offset from the terrestrial baseline (fauna) of 470 years, we must con- sider that, in theory, at Dereivka I the FRE offset could be anything from zero (9.9\% being a terrestrial diet signature) through to a ca. 350 year offset based on the human values obtained to date. However, it is important to emphasise that we cannot assume the degree of ${ }^{14} \mathrm{C}$ offset is systematic across the Dnieper region, or assume resource equivalence in terms of $\delta^{15} \mathrm{~N}$ baseline values between Yasinovatka and Dereivka I, which are located in different ecozones and different parts of the Dnieper system.

There are a number of challenges associated with unravelling freshwater radiocarbon reservoir effects at prehistoric sites (see Guiry 2019 for a review of the biogeochemical processes involved). Furthermore, there is an open debate in the academic literature concerning which statistical technique to apply to calculate ${ }^{14} \mathrm{C}$ offset. Most commonly, various forms of linear regression models are used (Schulting et al. 2014; 2015), with other studies preferring a Bayesian approach (Bronk Ramsey et al. 2014; Sayle et al. 2016).

A dedicated study investigating the freshwater radiocarbon reservoir effect at a number of prehistoric micro-regions in Lake Baikal, Siberia has shown that developing a correction for the FRE is not a straight-forward process. Weber et al. (2016) analysed 42 pairs of radiocarbon ages from human bone and terrestrial herbivore bone or tooth samples alongside $\delta^{15} \mathrm{~N}$ and $\delta^{13} \mathrm{C}$ values to calculate a correction factor using the linear regression methods developed by Schulting et al. (2014; 2015). Even with the significantly larger dataset, and multiple technique approach, they note that not only does the predictive power of these regression models vary notably between micro-regions (in some cases the regression equations explain less than $50 \%$ of the variation observed), there are also a number of cases where $\delta^{13} \mathrm{C}$ values are better predictors of ${ }^{14} \mathrm{C}$ variation than $\delta^{15} \mathrm{~N}$ values (Weber et al. 2016, p. 82).

To reiterate, the comprehensive freshwater reservoir effect study at Lake Baikal has 42 paired dates within an overall dataset of 256 AMS determinations, and despite this dataset the authors could not fully resolve the ${ }^{14} \mathrm{C}$ offset. In the Dnieper region we have 2 paired dates. As such, it is apparent that, at present, there is no simple correction factor that can be uniformly applied to radiocarbon ages across the Dnieper River cemeteries.

4. Verteba Cave. Recent research undertaken at the site of Verteba Cave in western Ukraine has resulted in the production of a number of papers, by different research teams, following on from the initial investigations by Alex Nikitin and Mykhailo Sokhatsky between 2005 and 2008 (Nikitin et al. 2010; 2017; Nikitin 2011). Whilst there is no denying the fact that this location is exceptional for many reasons, not least due to the extremely long use of this cave as a location for 
the deposition of human remains, certain aspects of the research that has been produced from investigations at this location require redress. Amongst the topics that have arisen from the recent research at this site, and which could be seen to require some further consideration, is the suggestion that Verteba Cave can be used to assess the shift from fisher-hunter-forager subsistence economies to farming economies in Ukraine. In this context Karsten and co-workers (e. g. Karsten et al. 2014; 2015b) have contrasted the pathologies in evidence at Verteba to those identified by Lillie (1998a) in the Dnieper region, suggesting that these pathologies demonstrate the impact of the transition to farming in Ukraine on overall health status.

The fact that there are consequences in terms of oral and overall health status at the transition to farming is a well-established fact, but, the point is that the pathologies that are reported for the individuals studied at Verteba, which are all assumed to be Trypillian farmers (an observation that is brought into question below), do not represent a continuum, in subsistence terms, for the populations of Ukraine as they transition from hunting, fishing and foraging to farming. One key issue lies in the fact that Verteba is ca. 500 $600 \mathrm{~km}$ west of the Dnieper Rapids region, where Lillie (1998a) undertook his study, and a second issue is that Trypillia groups are not the populations who develop from the groups interred in the Dnieper-Donets Mariupol-type (DD M-t) cemeteries, which is convincingly proved by anthropological and archaeogenetic studies (Potekhina 2018). The hunter-fisher-forager groups in and around the Dnieper do not transition to agriculture until much later, and even when we see forager-farmer interactions, only limited elements of the farming «package» are integrated into subsistence strategies. It is invalid to suggest that pathologies recorded on the possible Trypillia (or chronologically equivalent) individuals from Verteba (or those from any period between the Mesolithic and later historical periods), can be considered to be suitable for comparative purposes for the simple fact that the subsistence differences and sociocultural trajectories of the DD groups interred in the Mt cemeteries are distinct from Trypillia, and cannot realistically be compared because DD groups do not develop farming; and ultimately, partially due to a failure to adapt, Trypillia fails (Kruts 2012, p. 230).

Referring back to the suggestion that it is erroneous to assume that all of the individuals studied at Verteba are Trypillian in origin, we must return to the issues surrounding the lack of absolute dating of the remains from Verteba as discussed by Lillie et al. (2015; 2017; 2020), and whilst Madden et al. (2018, p. 901) have previously stated the following: "Lillie et al. (2017) have suggested dating and isotopic testing for all remains at the cave to ensure their provenance, while this would improve our understanding of the use of the cave and the Tripolie (Trypillia) culture it would also require destruction of what is a unique sample. This population is a non-renewable resource informing us of the past, we must be careful to balance potential knowledge gained with current technology against preservation of the remains for the future (Makarewicz and Sealy, 2015)».

This is a somewhat trite statement which belies the fact that the approaches adopted by these researchers at Verteba have failed to adequately demonstrate that the remains being studied are contemporary, and as Ledogar et al. (2019) clearly demonstrate, Mesolithic through to modern cultural material and human remains are in evidence at this location. In actual fact, and apparently contra Madden et al. (2018, p. 901), Ledogar et al. (2019, p. 141) state that understanding the chronology of Verteba cave is integral to further interpretations of the material evidence from Verteba (our emphasis). The simple fact is that all of the studies that have been produced that group together undated material from secondary contexts are fundamentally and methodologically flawed, and these studies have simply failed to meet the basic requirements of rigour in scientific approach that should be anticipated.

Logic and good science dictates that when the available evidence clearly indicates that stratigraphical integrity cannot be assured and that co-mingling of sequences has been clearly demonstrated (as outlined in detail below), treating the material from Verteba as an homogenous collection of Trypillia individuals for the purposes of producing a seemingly numerically significant/ satisfactory dataset is unjustifiable, at best. The fact that the studies prior to Ledogar et al. (2019) perpetuate these unsound assertions is perhaps made more problematic given that a number of other studies (e. g. Lillie et al. 2015; 2017) emphasised that, in light of the evidence from these studies and those of Nikitin (2011; Nikitin et al. $2010 ; 2017)$ absolute dating is essential to ensure that the conclusions of previous studies (e. g. Karsten et al. 2014; 2015a; 2015b) into the palaeopathological markers in evidence are accurate, and that all of the individuals used in these studies are, in fact, Trypillian in date.

Further issues arise in the reporting of the material from Verteba Cave with the observation that in their 2019 study Ledogar et al. (2019, p. 151) state that «Probability distributions for the ${ }^{14} \mathrm{C}$ dates suggest that there may have been either two periods of occupation, or two discrete events resulting in deposits during the Eneolithic» (fig. 4). As such, with this basic observation in place, it is clear that the grouping and treating of the Verteba material as an homogenous assemblage immediately fails to account for the fact that the pathologies in evidence actually represent at least two phases of deposition. 
However, of even greater concern is the fact that Lillie et al. (2017, p. 313) had previously stated that their «Figure 4 highlights the fact that the calibrated dates separate out into what appears to be three discrete phases of activity, an observation that would be consistent with the evidence from the palaeopathology" (evidence for healed trauma suggesting that low levels of repeated interpersonal violence are attested at Verteba; fig. 5; 6). Of note here is the fact that no mention is made of the previous studies undertaken by Lillie and co-workers $(2015 ; 2017)$ by Ledogar et al. (2019), who instead chose to focus on the stable isotope work by Lillie and co-workers, as this does not undermine the premise of their 2019 paper. In addition the AMS dates in Lillie et al. (2015; 2017) also extend the period of use at Verteba, back to pre 3900 cal BC, thus reinforcing the work of Nikitin et al. (2010). Importantly, as the Trypillia material is co-mingled with material of both earlier and later date, and there are at least two, and possibly three depositional events at Verteba during the Trypillia phases, it is an established fact that stratigraphic integrity simply cannot (and should not) be assumed for the material culture and human remains from Verteba.

As noted by Lillie et al. (2020), a total of 33 conventional dates from the Kiev radiocarbon facility, were reported in Nikitin et al. (2010), 14 of which were made on human remains (bone collagen) from the cave site. These dates primarily spanned the periods ca. $3600-2500$ cal BC (Trypillia CI-CII), but large errors, e. g. Ki14308 at $4910 \pm 400 \mathrm{BP}$ (rib fragment), extended the range to $4652-2674$ cal $\mathrm{BC}$. The combined dates on pottery and human bone did extend the use of the cave back into the period of activity of the Shypynetska culture grouping of Trypillia, who used the cave ca. $3745-3550$ cal BC (i. e. prima-

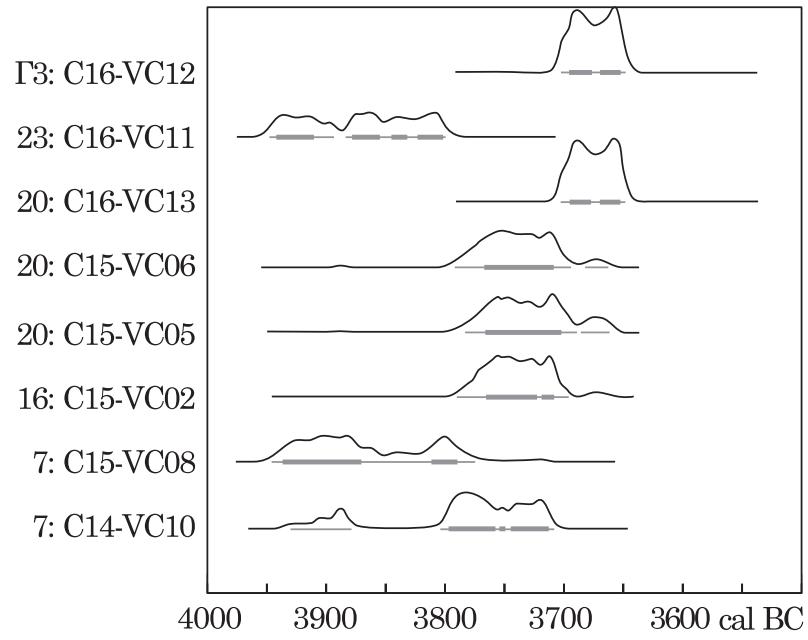

Fig. 4. Probability distributions for the calibrated dates for the eight samples from Verteba Cave that are associated with the Eneolithic (after Ledogar et al. 2019)

rily into Trypillia stage BII). Fundamentally, the work of Nikitin et al. (2010) and Lillie et al. (2017) has clearly demonstrated that the earlier dates for Trypillia activity equate to stage BII of Trypillia and that subsequent activity extends the periods of cave use into stage CI and CII of this culture. Lillie et al. (2020) note that in addition to refining the earlier work of Karsten and co-workers this is also clearly contra Kadrow and Pokutta (2016, p. 3) who state that "the oldest traces of human activity at the Verteba Cave come from the late CI phase and are associated with the Shipentsy group, living near the Badrazhy group on the central Dniester Plateau». Importantly, Nikitin et al. (2010, p. 15) also noted that the use of the cave was not continuous, as attested to by sterile horizons between cultural layers, and that use by the

OxCal v4.2.2 Bronk Ramsey (2013); r:5 Atmospheric data from Reimer et al. (2009)

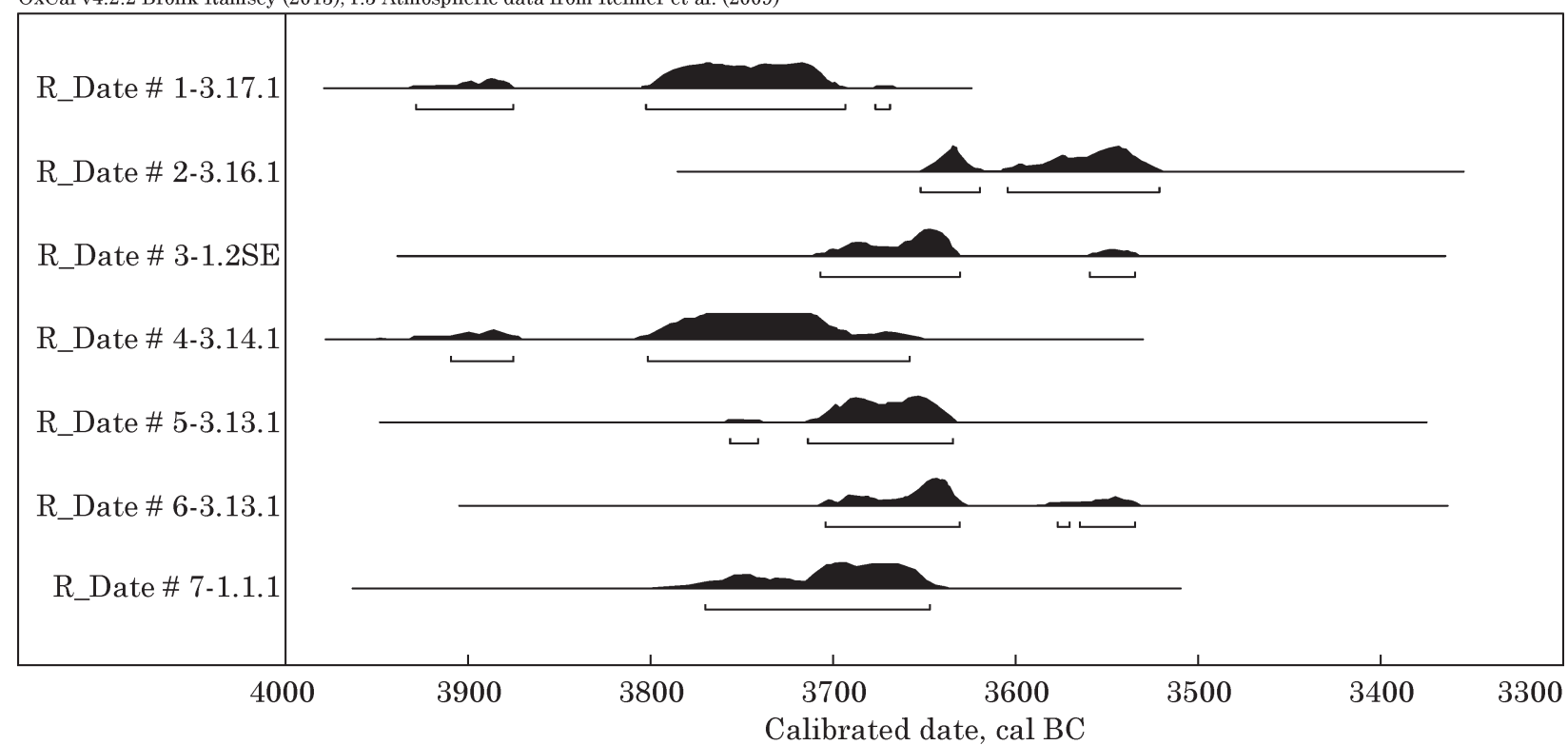

Fig. 5. AMS distribution plots for the individuals analysed by Lillie et al. $(2015 ; 2017)$ 


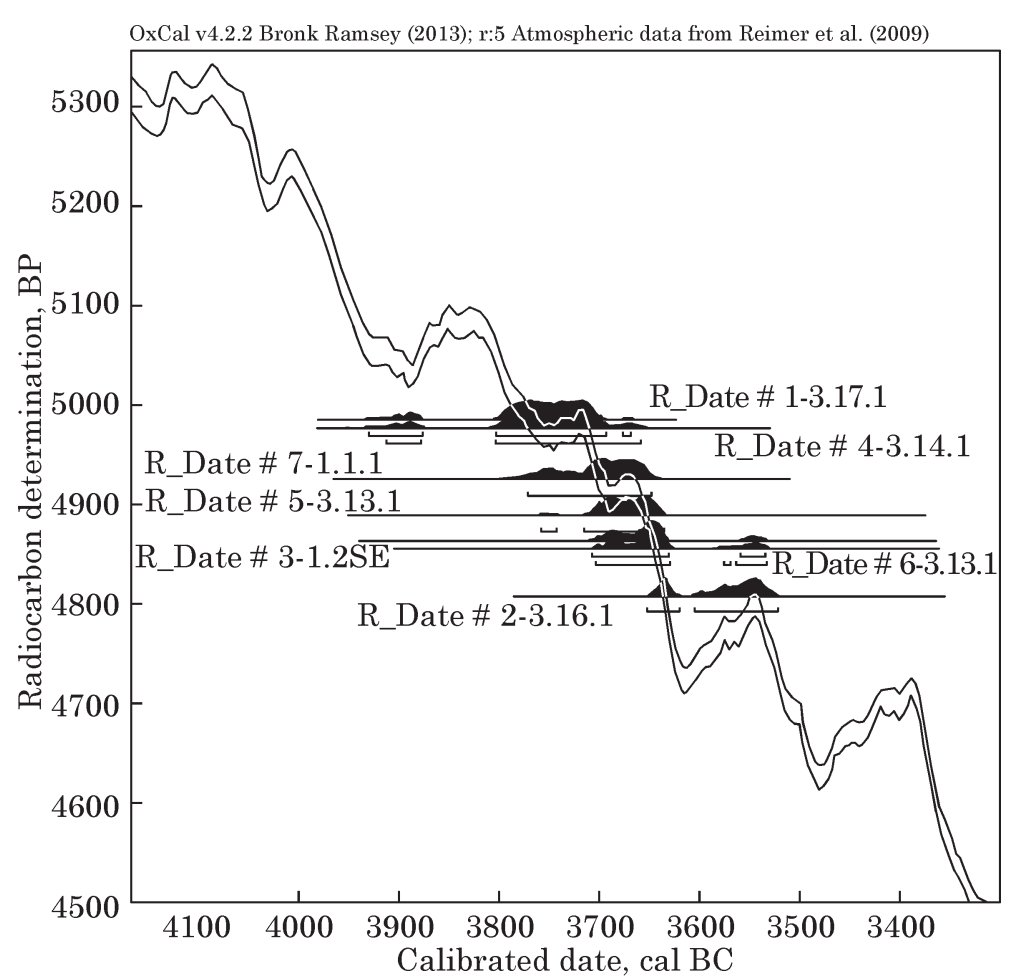

Fig. 6. Calibrated dates plotted on the radiocarbon curve - note that the location of the dates would indicate at least two or three discrete phases of deposition for these skulls (from Lillie et al. 2017)
Koshylovetska and Kasperivska groups occurred between ca. $3550-2747$ cal BC.

In addition to the evidence from the radiocarbon dating at Verteba, DNA analysis undertaken by Nikitin and co-workers (e. g. Nikitin et al. 2017) has shown that the individual's analysed exhibit a typical Neolithic farmer package of mitochondrial DNA (mtDNA), with lineages traced to Anatolian farmers and Neolithic farming groups of central Europe. At the level of mtDNA haplogroup frequencies the TC population from Verteba demonstrates a close genetic relationship with population groups of the Funnel Beaker / Trichterbecker cultural complex from central and northern Europe (ca. $3950 \pm 2500 \mathrm{BCE}$ ). Furthermore, two specimens belong to haplogroup U8b1 at Verteba, and these individuals can be viewed as a connection of Trypillia Culture (TC) groups with the Upper Palaeolithic populations of Europe.

The DNA analysis obviously provides important insights into the genetic origins of the Trypillia groups that used Verteba, but, importantly, an additional issue is highlighted by Nikitin's work. This relates to the suggestion that the dating and stable isotope values obtained by Ledogar et al. (2019) on a $2^{\text {nd }}$ and $4^{\text {th }}$ metacarpal, are from discrete individuals, an observation that is subject to question. DNA analysis by Nikitin (pers comm. 16/11/2019) has already shown that there are two metacarpals (left and right hand) excavated in May 2008 which appear, genetically, to be from the same individual. Importantly for the current discussion is the observation that one of the metacarpals was found near the surface (alluvial deposit, level 1) in the SE corner of quadrant 1 at Verteba, whilst the other was found at level 3 (within or on top of the clay matrix of the cave floor) in the NW corner. As both elements appear (genetically) to belong to the same person, the obvious conclusion must be that there is some considerable mixing between levels. Given the comingled, secondary depositional, context of the material at Verteba, caution is clearly warranted when analyzing material that cannot be shown to be from discrete individuals.

Thus, the observation that the dating and stable isotope values obtained on a $2^{\text {nd }}$ and $4^{\text {th }}$ metacarpal, are from discrete individuals at Verteba Cave (Ledogar et al. 2019, p. 148, table 2, fig. 3) should be queried (see table 1), especially given the close correspondence of the isotope values from these «individuals» $\left(\delta^{13} \mathrm{C}\right.$ of $-19.8 \%$ and $19.8 \%$ and $\delta^{15} \mathrm{~N}$ of $9.8 \%$ and $9.9 \%$ respectively), and the identical AMS dates obtained.

Importantly, Ledogar et al. (2019, p. 152) state that "The ${ }^{14} \mathrm{C}$ ages for bone samples from site 20, 4955 $\pm 25 \mathrm{BP}$ (CC167135), 4965 $\pm 25 \mathrm{BP}$ (CC167136), and 4900土 $20 \mathrm{BP}$ (CC169195), were compared and are not statistically different $\left(T=0.78, x^{2}=5.99\right.$ at $\left.a=0.05 ; d f=2\right)$ suggesting that the strata from these deposits are contemporaneous». The problem appears to be that there is an identical date being reported from a different context. However, the subsequent statement by these authors (2019, p. 152) that CC169195 is in fact from site 20 and not location $\Gamma 3$ is problematic, and perhaps highlights some confusion in the reporting of these finds (which can happen obviously). As noted above, the isotope data and AMS dates would strongly suggest that these elements are from the same individual. Consequently, and given the lack of stratigraphic integrity at Verte- 
Table 1. Identical AMS dates for elements from differing locations at Verteba Cave (after Ledogar et al. 2019)

\begin{tabular}{|c|c|c|c|c|c|c|c|c|c|}
\hline Site & L/F & Lab\# & Sample\# & Taxon & Element & Age & $\begin{array}{c}\text { Fraction } \\
\text { Modern }\end{array}$ & ${ }^{14}$ C, BP & $2 \sigma$ date, cal BC \\
\hline 20 & L2 & CC169199 & C15-VC13 & Homo sapiens & $4^{\text {th }}$ metacarpal & A & 0.54 & $4900 \pm 20$ & $3704-3648$ \\
Г3 & L3 & CC169195 & C16-VC12 & Homo sapiens & $2^{\text {nd }}$ metacarpal & A & 0.54 & $4900 \pm 20$ & $3704-3648$ \\
\hline
\end{tabular}

Abbreviations, here and in table 4: L - level, $\mathrm{F}$ - feature, Ob - overburden, $\mathrm{Sf}$ - surface, $\mathrm{A}$ - adult, $\mathrm{S}$ subadult.

Table 2. Strontium, oxygen and carbon isotopic composition of tooth enamel of three individuals from Verteba Cave (after Madden et al. 2018)

\begin{tabular}{|c|c|c|c|c|c|c|c|}
\hline Sample & Element & Age, years & $\begin{array}{c}\text { Tooth formation, crown } \\
\text { complete, years }\end{array}$ & Sex & $87 \mathrm{Sr} / 86 \mathrm{Sr}$ & $\begin{array}{c}\delta^{13} \mathrm{CvPDB}, \\
\% 0\end{array}$ & $\begin{array}{c}\delta^{18} \text { OvSMOW, } \\
\% 0\end{array}$ \\
\hline EA14 & $3^{\text {rd }}$ left maxillary molar & $17-25$ & $12-16$ & Male & 0.70975 & 11.8 & 23.8 \\
EA15 & Canine & $25-35$ & $6-7$ & Male & 0.70931 & 11.9 & 23.4 \\
EA16 & Left lateral maxillary incisor & $25-35$ & $4-5$ & Male & 0.70966 & 11.5 & 23.7 \\
\hline
\end{tabular}

Table 3. Sr, $\delta^{13} \mathrm{C}$ and $\delta^{18} \mathrm{O}$ results from human and pig samples at Verteba (after Lillie et al. 2017)

\begin{tabular}{|c|c|c|c|c|c|c|c|}
\hline Species & Individual & Sample ID & Element & Sex & ${ }^{87} \mathrm{Sr} /{ }^{86} \mathrm{Sr}$ & $\delta^{13} \mathrm{C}$ & $\delta^{18} \mathrm{O}$ \\
\hline Human & 7 & V1.1.1 & Max right M2 & M & 0.709660 & 13.12 & 5.80 \\
Human & 3 & V3.18.1 (1.2) & Max left P3 & F & 0.709741 & 12.86 & 6.98 \\
Human & 4 & V3.14.1 & Max right P4 & M & 0.709616 & 11.99 & 6.83 \\
Human & 6 & V3.15.1 & Max Right M1 & M & 0.709692 & 12.86 & 6.48 \\
Human & 2 & V3.16.1 & Max right P3 & M & 0.709312 & 12.64 & 6.31 \\
Human & 1 & V3.17.1 & Max Left M1 & M & 0.709842 & 12.30 & 6.39 \\
Human & 8 & A22 & Incisor & I & 0.709344 & 12.17 & 5.83 \\
Human & 9 & M5 & Mand right PM2 & M & 0.709475 & 9.12 & 5.94 \\
Pig-F2 & - & F2.6.2 & Incisor & - & 0.709100 & - & - \\
Pig & - & F2.6.4 & Mand right PM2 & - & 0.709700 & - & - \\
\hline
\end{tabular}

Text Highlighted in Grey are samples that have identical 87Sr/86Sr ratios to samples EA16 and EA15 in the Madden et al. (2018) study: discussed in the text

Table 4. Identical AMS dates for elements from differing locations at Verteba Cave (after Ledogar et al. 2019)

\begin{tabular}{|c|c|c|c|c|c|c|c|c|c|c|}
\hline Site & L/F & Lab\# & Sample\# & Taxon & Element & Age & $\begin{array}{c}\text { Fraction } \\
\text { Modern }\end{array}$ & ${ }^{14} \mathrm{C}$ BP & $2 \sigma$ date & cal BC/AD \\
\hline Г3 & Sf. & CC-167139 & C15-VC09 & Homo sapiens & Parietal & A & 0.85 & $1315 \pm 25$ & $\begin{array}{c}656-780,76 \% ; \\
741-766,24 \% \\
778-730,22 \% ;\end{array}$ & cal AD \\
Г3 & L.1 & CC-169196 & C16-VC17 BC & Canis familiaris & Metapodial & A & 0.73 & $2505 \pm 20$ & $\begin{array}{c}692-659,17 \% ; \\
651-543,61 \%\end{array}$ & \\
\hline
\end{tabular}

ba, a note of caution is warranted both in terms of methodological approaches that assume that all elements are from discrete individuals (a clearly untenable assumption), and where near identical data is generated the possibility that the same individual has been analyzed must surely be taken into account (a point that is touched upon further below).

As the evidence indicates, the remains at Verteba are secondary deposits, as such, the finds of smaller elements from the same individ- ual suggests that the remains were relocated to Verteba prior to full disarticulation occurring at the primary point of interment / processing. This actually adds another interesting new aspect to the rituals in evidence at Verteba, and would corroborate the observations by Lillie et al. (2015; 2017) that the processing and inclusion of the remains into the cave deposits probably occurred relatively soon after the death of the individual.

With the above observations in mind it is obviously equally fictitious to assert that all of the 
trauma in evidence at Verteba can be wholly assigned to a single stage of the Trypillia culture, as the available dating contradicts this, and equally, the lack of absolute dating of comingled / mixed deposits precludes such an assertion. It is apparent that the failure by Karsten and co-workers to date every sample (prior to the Ledogar et al. 2019 paper) suggests that there was a working assumption that the remains were Trypillian in age and as such, contemporary, but this is disproven. Additionally, there is a knock-on effect to all previous studies by these authors in that the grouping of the material from Verteba, and the implied contemporaneity, is at best an error of judgement, and at worst misleading. Similarly, suggesting that the available evidence attests to a CII age for the trauma in evidence is also somewhat economical with the facts, in that the dating by Nikitin (2011; Nikitin et al. 2010, and subsequently Lillie et al. 2015; 2017) had already shown / has shown that the material that equates to Trypillia is also dated to stages BII and CI of this culture (and possibly slightly earlier), thus establishing the fact that inter-personal violence occurs before the decline of Trypillia. This fact is actually far more interesting in research terms, as the available evidence indicates that low level endemic violence may characterise this farming culture across the main stages of its evolution, an observation that was not possible prior to the discovery of Verteba Cave, as the skeletal record for Trypillia is lacking in general, and very poor for the earlier stages of this culture.

Further irregularities are highlighted between the studies of Lillie et al. 2017 and Madden et al. 2018 in the reporting of strontium isotopes from Verteba. In their 2018 study Madden et al. (2018, p. 899) present the data in table 2 showing the strontium, oxygen and carbon isotope results from three individuals at Verteba.

Previously Lillie et al. (2017, p. 316) produced the results in table 3 for 8 human for 8 human and 2 pig samples from Verteba Cave.

Whilst the $\delta^{13} \mathrm{C}$ and $\delta^{18} \mathrm{O}$ ratios differ for two of the individuals analysed by Madden et al. (2018) it is intriguing to note the identical ${ }^{87} \mathrm{Sr} /{ }^{86} \mathrm{Sr}$ ratios between individual EA15 in the Madden et al. (2018) study and individual 2 in the Lillie et al. (2017) study, and the identical ratio for individual EA16 when compared to individual 7 in the Lillie et al. (2017) study (table 3: highlighted text). Whilst the $\delta^{13} \mathrm{C}$ and $\delta^{18} \mathrm{O}$ ratios are not comparable between these two studies, it might be worthwhile identifying whether the individuals with identical strontium values are in fact the same individuals, as given the finite nature of the resource, it is clear that different research teams need to work in synergy in order to reduce replication of analyses and thus propagate a reduction in the available resource. Of course, the fact that two individuals have produced identical Sr ratios is also somewhat unusual in itself.
5. Additional Observations. Ledogar et al. (2019, p. 149) observe that at Verteba «Nitrogen values for two of the humans, two dogs, and one pig are at the same trophic level (9.0-10.5\%) as the freshwater species, while the other humans, pig, dog, and chicken (2.7-8.4\%o) fall below the trophic level of the freshwater species». The dating, alongside the nitrogen diet isotope values of $2.7 \%$ and $2.9 \%$ for human and dog remains from Verteba suggest that the $\Gamma 3$ site represents a mixed location with dates of the dog across three periods between $778-543 \mathrm{cal} \mathrm{BC}$ and the human placed across two periods between $656-780$ cal AD (Iron Age and Scythian; table 4).

Whilst at face value the $2.7 \%$ and $2.9 \%$ nitrogen isotope values for the Iron Age dog and Scythian human appear to be reliable results, the fact that Ledogar et al. (2019) note that they are inconsistent with the data from Murphy et al. (2013), and in fact are inconsistent with all other studies undertaken on the remains from Ukraine to date, is potentially cause for concern.

It is clear that the application of a technique such as ZooMS (Zooarchaeology by Mass Spectrometry) should be considered to verify the identification of these samples. The isotope values are in fact well below all those of previous studies and also generally well below those in Ledogar et al. (2019). As such, stating that they suggest a «strongly herbivorous diet» (2019, p. 154) needs to be tested as these values do not reflect trophic enrichment (which would be expected) or the nature of the data that has been generated up to this point. In general, whilst the majority of the data at Verteba is consistent with the ratios that would be expected for humans consuming terrestrial diets wherein $\mathrm{C}_{3}$ resources are being consumed, and the data are consistent with the levels identified by Budd and Lillie (2020) for the Mesolithic through to Eneolithic periods further east in the Dnieper Basin, that are associated with terrestrial diets, the values of $2.7 \%$ and $2.9 \%$ need to be investigated further given their anomalous nature in relation to the available data from Ukraine as a whole.

One further observation is that Ledogar et al. (2019, p. 153) state that "Populations in Mesolithic Ukraine have been considered hunter-fisher-gatherers who relied heavily on animal protein; however, the isotopic data from individual CC167136 from Verteba Cave suggests that he or she consumed much more plant protein. While the data from this study is only the diet of one individual, it does introduce the possibility that diet was quite variable across the region at this period». Lillie et al. (2009; 2010; Lillie 1998 and a number of other papers by these authors) had actually already stressed that Mesolithic diets did not rely heavily on animal protein, and they had also already noted the fact that variability in diet was occurring, and in actuality the data continues to highlight this (Budd, Lillie 2020). The reader is 
directed towards Lillie et al. (2020), Lillie (2020) and Budd and Lillie (2020) for a detailed critique of the Ukrainian evidence.

6. Discussion. The identification of an emphasis on aquatic resources from the Epipalaeolithic period onwards in the Dnieper region is significant for Ukraine as it is generally assumed that broad-based resource procurement strategies are more characteristic of later, post-glacial or Mesolithic groups (Dolukhanov 2000, p. 78). Importantly, as noted by Lillie (2003a), it also suggests that the preoccupation with the exploitation of large game animals, that characterises discussions of prehistoric subsistence strategies in Ukraine (Balakin, Nuzhinyi 1995; O'Connell et al. 2000), fails to account for the reality, especially given the considerable evidence for the exploitation of aquatic resources; resources which clearly formed an essential element of Epipalaeolithic through to Eneolithic diets across the early to mid-Holocene. It is also likely that fish-based proteins periodically increased in significance across the Epipalaeolithic to Eneolithic periods for various socio-economic, environmental and even ritualised reasons. To reiterate however, it should be remembered that the designation of "Neolithic» for Ukraine does not necessarily equate to the "traditional» observation of an associated shift towards the exploitation of domesticated plants and animals, and as such continuity in subsistence practices across the early to mid-Holocene is not atypical for many regions of Eastern Europe.

The fact is that fish, and freshwater resources, are an important dietary staple from the Epipalaeolithic period onwards, and it would be fictitious to suggest that the exploitation of these resources represents the exploitation of a "starvation food» that is only relied upon during periods of resource stress. Amongst the fantasies that are highlighted in dietary studies is the idea that meat consumption is the «be all and end all» of the subsistence spectrum during the earlier Holocene. Furthermore, it appears that we see diversification in subsistence strategies between the Epipalaeolithic and later Mesolithic periods as the data suggest that a broader dietary spectrum was being exploited in the latter period as plant and animal resources expand and diversify (Budd, Lillie 2020). The isotope data also demonstrate that as early as ca. $7000-6600$ cal BC there is evidence to suggest that certain individuals, in this case at the cemetery of Marievka, were consuming diets that were predominantly based on the consumption of terrestrial as opposed to freshwater resources (ibid. 2020). Throughout the Neolithic period the data again indicate that a heavy reliance is placed upon the exploitation of freshwater resources, especially at the sites of Yasinovatka, Nikolskoye and Dereivka I. At Yasinovatka, Vasilyevka V, and Dereivka I we again have individuals who were consuming terrestrial as opposed to aquatic dominated diets.
By the Eneolithic period diversification is occurring. The isotope analysis at Igren VIII indicates a heavy reliance on freshwater resources, but at Molukhov Bugor the data indicate that more varied diets were being consumed, albeit with freshwater resources still forming an integral element of subsistence strategies. The main point of departure, as might be anticipated, is the evidence from Verteba Cave in western Ukraine, where the diet isotope data supports the exploitation of terrestrial dietary pathways for the (presumed) Trypillia farmer groups who interred their dead in secondary contexts at this location.

As has been emphasised elsewhere (Lillie et al. 2009), the heavy reliance on freshwater resources across the Epipalaeolithic through to Eneolithic periods in and around the Dnieper river system in Ukraine is resulting in a radiocarbon freshwater reservoir effect (FRE) that is impacting on the dating of the individuals interred in the DR M-t cemeteries of Ukraine. The discussion above has highlighted the fact that there is no simple correction factor that can be applied at the whole cemetery level due to the variations in $\delta^{15} \mathrm{~N}$ values that are in evidence. However, the fact that there are individuals at a number of cemeteries who consumed diets that were dominated by terrestrial resources, and who exhibit values for $\delta^{15} \mathrm{~N}$ across the range of ca. 9-11\%, does offer some potential for future studies aimed at refining the FRE correction factors at certain locations.

Finally, the discussion throughout this paper has sought to highlight areas where research agenda's overlap, and where the research itself is occasionally perhaps lacking somewhat in methodological and scientific rigour. In this context the research undertaken at Verteba Cave has proven fruitful in terms of a critique of methods and the dissemination of results. Whilst this overview is envisioned as an appraisal of the state of play up to this point, it is not intended to be critical per $s e$, as there are many pitfalls in the development of new and innovative research agenda's. This is especially so in regions such as Ukraine, where the history of research makes it difficult to gain a rapid overview of cultural developments, and where the application of scientific methodologies such as AMS dating and isotope analyses are still relatively new in studies of past human groups. The costs involved in the application of these techniques can be prohibitive, and it is clear from the studies at sites like Verteba Cave in western Ukraine, that the work of different research teams can intersect, and that this can on occasion lead to inconsistencies and overlaps in the reporting of research findings. Undoubtedly concerted research efforts aimed at ensuring synergy in approach and securing funding for long-term studies must form an integral aspect of future research in Ukraine.

Conclusions. At present the majority of the cemeteries studied from the Dnieper Basin ex- 
hibit either long periods of interment, or multiple phases of use, or both, this is the case for many DD/M-t cemeteries, and is also true for Verteba Cave in western Ukraine. Verteba Cave itself is unique in the myriad ritual activities that are attested, and in offering insights into the Trypillia culture that would have been impossible to disentangle without such a location. Of some significance is the observation that low levels of endemic inter-personal violence may well have characterised this population across stages BII to CII of its existence, and of course it is conceivable that such activities may have characterised the Trypillia culture in general.

The data has shown that in the Dnieper region the exploitation of freshwater resources is occurring from the Epipalaeolithic through to Eneolithic periods, and whilst there is some variability in evidence, prehistoric diets were not simply focussed on the exploitation of large game animals. Freshwater resources were stable resources in a changing environment and it is likely that all of the resources of the riparian zone were being exploited across the Epipalaeolithic through to Eneolithic periods and beyond. Logically we now need to undertake full cemetery analyses for all of the periods that have been studied to date, and to extend the analyses into the later prehistoric periods to try to elucidate the nature of the adoption of domesticated resources by subsequent culture groups, whilst also expanding the analyses further, beyond the areas that are currently being studied.

It is apparent that concerted collaborative efforts are needed to ensure that the study of prehistoric populations are systematic, integrated and targeted to ensure that realistic interpretations and conclusions are being generated from studies in the territory of Ukraine. It is also readily apparent that replication of data is wasteful in terms of research time and resources, and given that Madden et al. (2018, p. 901) state that Verteba is a "unique» and a "non-renewable resource» the potential analysis of the same individuals as identified above would reinforce the need for dialogue and synergy in approaches to such data. Similarly, the avoidance of misrepresentation or misuse of data from previous studies, which undermines the discipline and the peer review process somewhat, and weakens the value of the scientific research that has been undertaken over the past three decades (particularly so in the case of dating and isotope studies), is fundamental if the research being produced is to remain valid, authorised and significant.

Unfortunately, the fact is that despite our studies since 1992-1993, there is still a lot of analysis that needs to be undertaken if we are to adequately characterise the socio-cultural and economic development of the prehistoric populations of Ukraine, not least because the majority of our research has focussed on the populations in and around the Dnieper river system due to the exceptional preservation of human skeletal remains in cemeteries from the earliest Holocene through to ca. 3500 cal BC (and beyond) in this region. Throughout our research program a lack of resources has inhibited the degree to which dating and dietary isotope studies have been able to be applied. Ukraine has been shown to be exceptional in terms of its prehistoric cultural developments, the existence of cemeteries from as early as ca. 10,200 cal BC and their use across all periods of prehistory, the fact that the genetic data indicates that the Yamnaya culture is pivotal in terms of the origins of the Indo-Europeans, and that it is likely that earlier Sredni-Stog culture groups may well be central to these developments (e. g. Mathieson et al. 2018). Future research agendas now need to expand upon the foundations that have been established and undertake whole cemetery multi-disciplinary analyses in order to further enhance our understanding of socio-economic and societal developments during the early to mid-Holocene in Ukraine.

Acknowledgements. We would particularly like to thank Professor, Dr. Hab. Dmytro Telegin (to whom this paper is dedicated) and Dr. Inna Potekhina, as, without their help, guidance, collaborative spirit, inspiration, and advice the early research would have been far more difficult and onerous. We would also like to thank Alexei Nikitin for discussions around the DNA analyses, and for advice and opinions in relation to our thoughts regarding Verteba cave. Also, Mykhailo P. Sokohatskyi was kind enough to invite MCL to visit Verteba in 2011, with Dr. Inna Potekhina, and Prof. Aleksandr Potekhin drove us from Kiev to Verteba, no easy undertaking given the road conditions away from the major urban centers.

Professor Lillie would also like to make mention of two colleagues who are also no longer with us, but who both in their own ways helped him throughout the earlier years of his research firstly Professor Timofeev (St. Petersburg) who helped with access to the collections housed in St. Petersburg and with an extended visit during the early part of the research agenda, and secondly Professor Dolukhanov, who was always helpful in offering advice and access to papers across a significant part of the research. Pivotal, in terms of Lillie's academic development was, of course, his PhD supervisor the late Professor Marek Zvelebil, one of the more influential thinkers in earlier Prehistoric studies. They are all missed.

Funding. A NERC-AHRC National Radiocarbon Facility (NRCF) grant (to MCL) provided funding for the AMS Dating presented in the Lillie et al. 2015; 2017 papers (Project - No. $\mathrm{NF} / 2011 / 2 / 18$ ). In addition, WAERC (Wetland Archaeology \& Environments Research Centre) at the University of Hull (now based at Umeå University in Sweden) funded a considerable amount of the dating and isotope work that has been undertaken since 1991-1992. 


\section{REFERENCES}

Ambrose, S. H. 1990. Preparation and characterization of bone and tooth collagen for isotopic analysis. Journal of Archaeological Science, 17, p. 431-451.

Ambrose, S. H., Norr, L. 1993. Experimental evidence for the relationship of the carbon isotope ratios of whole diet and dietary protein to those of bone collagen and carbonate. In: Lambert, J. B., Grupe, G. (eds.). Prehistoric Human Bone: Archaeology at the Molecular Level. New York: Springer, p. 1-37.

Ascough, P., Cook, G., Dugmore, A. 2005. Methodological approaches to determining the marine radiocarbon reservoir effect. Progess in Physical Geography, 29, 4, p. 532-547.

Balakin, S., Nuzhinyi, D. 1995. The origins of graveyards: the influence of landscape elements on social and ideological changes in prehistoric communities. Préhistoire Européenne, 7, p. 191-202

Brock, F., Higham, T., Ramsey, C. B. 2010. Pre-screening techniques for identification of samples suitable for radiocarbon dating of poorly preserved bones. Journal of Archaeological Science, 37, p. 855-865.

Bronk Ramsey, C., Schulting, R. J., Goriunova, O. I. Bazaliiskii, V. I., Weber, A. W. 2014. Analyzing radiocarbon reservoir offsets through stable nitrogen isotopes and Bayesian modeling: a case study using paired human and fauna remains from the Cis-Baikal region, Siberia. Radiocarbon, 56, 2, p. 1-11.

Buckley, M., Collins, M., Thomas-Oates, J., Wilson, J. C. 2009. Species identification by analysis of bone collagen using matrix-assisted laser desorption/ionisation time-of-flight mass spectrometry. Rapid Communications in Mass Spectrometry, 23, p. 3843-3854.

Budd, C. 2015. Neolithic Anatolia and Central Europe: disentangling environmental impacts from diet isotope studies. Doctoral dissertation. University of Oxford.

Budd, C., Lillie, M. C. 2020. The prehistoric populations of Ukraine: stable isotope studies of fisher-hunter-forager and pastoralist-incipient farmer dietary pathways. In Lillie, M. C., Potekhina, I. D. (eds.). Prehistoric Ukraine: From the First Hunters to the First Farmers. Oxford: Oxbow Books, p. 283-307.

Budd, C. E., Lillie, M. C., Potekhina, I. D. 2020 Continuation of fishing subsistence in the Ukrainian Neolithic: diet isotope studies at Yasinovatka, Dnieper Rapids. Archaeological and Anthropological Sciences, 12, 2, article id. 64.

Ciuk, K. (ed.). 2008. Mysteries of Ancient Ukraine: the remarkable Trypilian Culture 5400-2700 BC. Canada: Royal Ontario Museum.

DeNiro, M. J. 1985. Post-mortem preservation and alteration of in vivo bone collagen isotope ratios in relation to paleodietary reconstruction. Nature, 317, p. 806-809.

DeNiro, M. J., Epstein, S. 1978. Influence of diet on the distribution of carbon isotopes in animals. Geochimica Cosmochimica Acta, 42, p. 495-506.

Dolukhanov, P. 1979. Ecology and economy in Neolithic eastern Europe. London: Duckworth.

Dolukhanov, P. M. 2000. Alternative revolutions: huntergatherers, farmers and stock-breeders in NorthWestern Pontic area. In: Boyle, K., Renfrew, C., Levine. M. (eds.). Ancient Interactions: East and West in Eurasia. McDonald Institute Monographs. Cambridge, p. 13-24.

Dolukhanov, P. M., Khotinskiy, N. A. 1984. Human cultures and the natural environments in the USSR during the Mesolithic and Neolithic. In: Vilechko, A. A. (ed.). Late Quaternary Environments of the Soviet Union. Minneapolis: University of Minnesota, p. 319-327.

Gimbutas, M. 1956. The Prehistory of Eastern Europe. I: Mesolithic, Neolithic and Copper Age Cultures in Russia and the Baltic Area. ASPR Bulletin, 20. Cambridge.

Hedges, R. E., Reynard, L. M., 2007. Nitrogen isotopes and the trophic level of humans in archaeology. Journal of Archaeological Science, 34, 8, p. 1240-1251.

Henderson, R. C., 2015. Early life histories: a study of past childhood diet and health using stable isotopes and enamel hypoplasia. PhD Thesis. Oxford University.

Jacobs, K. 1993. Human Postcranial Variation in the Ukrainian Mesolithic-Neolithic. Current Anthropology, 34, p. 417-430.
Jacobs, K., 1994. Human Dento-Gnathic Metric Variation in Meolithic / Neolithic Ukraine: Possible Evidence of Demic Diffusion in the Dnieper Rapids Region. American Journal of Physical Anthropology, 95, p. 1-26.

Kadrow, S., Pokutta, D. A., 2016. The Verteba Cave: a subterranean sanctuary of the Cucuteni-Trypillia Culture in western Ukraine. Journal of Neolithic Archaeology, 18, p. 121.

Karsten, J. K., Heins, S. E., Madden, G. D., Sokhatsky, M. P. 2014. The biological implications of the transition to agriculture in Ukraine: a study of enamel hypoplasias. International Journal of Dental Anthropology, 27, 1-2, p. 1625.

Karsten, Dzh., Sokhatskiy, M. P., Kheyns, S. G., Medden, G. D. 2015a. Bioarkheologicheskiy analiz antropologicheskogo materiala iz peshchery Verteba. Stratum plus, 2 , p. 121-144.

Karsten, J. K., Heins, S. E., Madden, G. D., Sokhatskyi, M. P. 2015b. Dental Health and the transition to agriculture in prehistoric Ukraine: a study of dental caries. European Journal of Archaeology, 18, 4, p. 562-579.

Kotova, N. 2018. Revisiting the Neolithic chronology of the Dnieper Steppe region with consideration of a Reservoir Effect for Human Skeletal Material. Sprawozdania Archeologiczne, 70, p. 47-66.

Kozlowski, S. K. 1989. A Survey of Early Holocene Cultures of the Western Part of the Russian Plain. In: Bonsall, C. (ed.). The Mesolithic in Europe. Edinburgh: J. Donald, p. 424441.

Krueger, H. W., Sullivan, C. H. 1984. Models for carbon isotope fractionation between diet and bone. In: Turnland, J. R. Johnson, P. E. (eds.). Stable Isotopes in Nutrition. Washington DC: American Chemical Society Symposium Series, 258, p. 205-220.

Kruts, V. 2012. The Latest Stage of Development of the Tripolye Culture. In: Menotti, F., Korvin-Piotrovskiy, A. G. (eds.). The Tripolye Culture Giant Settlements in Ukraine: Formation, Development and Decline. Oxford: Oxbow Books, p. 230-253.

Ledogar, S. H., Karsten, J. K., Madden, G. D., Schmidt, R., Sokhatsky, M. P., Feranec, R. S. 2019. New AMS dates for Verteba Cave and stable isotope evidence of human diet in the Holocene forest-steppe Ukraine. Radiocarbon, 61, 1, p. 141158.

Lillie, M. C. 1996. Mesolithic and Neolithic populations of Ukraine: indications of diet from dental pathology. Current Anthropology, 37, 1, p. 135-142.

Lillie. M. C. 1997. Women and Children in Prehistory: Resource Sharing and Social Stratification at the MesolithicNeolithic Transition in Ukraine. In: Moore, J., Scott, E. (eds.). Invisible People and Processes: Writing Gender and Childhood into European Archaeology. London: Leicester University, p. 213-228.

Lillie, M. C. 1998a. The Dnieper Rapids region of Ukraine: a consideration of chronology, dental pathology and diet at the Mesolithic-Neolithic transition. PhD Thesis. Sheffield University.

Lillie, M. C. 1998b. Cranial surgery dates back to Mesolithic. Nature, 391, p. 854.

Lillie, M. C. 1998c. The Mesolithic-Neolithic transition in Ukraine: new radiocarbon determinations for the cemeteries of the Dnieper Rapids region. Antiquity, 72, p. 184-188.

Lillie, M. C. 2003a. Tasting the Forbidden Fruit: gender based dietary differences among prehistoric hunter-gatherers of Eastern Europe? Before Farming, 2, 3, p. 1-16.

Lillie, M. C. 2003b. The Fruit and Nut Case: hunter-gatherer subsistence and egalitarianism in the riparian zone. In: Bevan, L., Moore, J. (eds.). Peopling the Mesolithic in a Northern Environment. British Archaeological Reports, International Series, 1157. Oxford: BAR Publishing, p. 59-68.

Lillie, M. C. 2020. Palaeopathology of the Prehistoric Populations of Ukraine. In: Lillie, M. C., Potekhina, I. D. (eds.). Prehistoric Ukraine: From the First Hunters to the First Farmers. Oxford: Oxbow Books, p. 235-281.

Lillie, M. C., Richards, M. P. 2000. Stable Isotope Analysis and Dental Evidence of Diet at the Mesolithic-Neolithic Transition in Ukraine. Journal of Archaeological Science, 27, p. 965-972. 
Lillie, M. C., Jacobs, K. 2006. Stable isotope analysis of fourteen individuals from the Mesolithic cemetery of Vasilyevka II, Dnieper Rapids region, Ukraine. Journal of Archaeological Science, 33, p. 880-886.

Lillie, M. C., Budd, C. 2011. The Mesolithic-Neolithic Transition in Eastern Europe: Integrating Stable Isotope Studies of Diet with Palaeopathology to Identify Subsistence Strategies and Economy. In: Pinhasi, R., Stock, J. T. (eds.). Human Bioarchaeology of the Transition to Agriculture. Chichester: John Wiley \& sons, p. 43-62.

Lillie, M. C., Richards, M. P., Jacobs, K. 2003. Stable Isotope Analysis of Twenty-one Individuals from the Epipalaeolithic Cemetery of Vasilyevka III, Dnieper Rapids region, Ukraine. Journal of Archaeological Science, 30, p. 743-752.

Lillie, M. C, Budd, C. E., Potekhina, I. D. 2011. Stable isotope analysis of prehistoric populations from the cemeteries of the Middle and Lower Dnieper Basin, Ukraine. Journal of Archaeological Science, 38, 1, p. 57-68.

Lillie, M. C., Budd, C. E., Potekhina, I. D., Hedges, R. E. M. 2009. The Radiocarbon Reservoir Effect: New Evidence from the Cemeteries of the Middle and Lower Dnieper Basin, Ukraine. Journal of Archaeological Science, 36, 2, p. 256-264

Lillie, M. C., Henderson, R., Budd, C. E., Potekhina, I. D. 2016. Factors influencing the radiocarbon dating of human skeletal remains from the Dnieper river system: Archaeological and stable isotope evidence of diet from the Epipalaeolithic to Eneolithic periods. Radiocarbon, 58, 4, p. 741-753.

Lillie, M. C., Budd, C. E., Potekhina, I. D. 2020. Radiocarbon dating of sites on the Dnieper Region and Western Ukraine. In: Lillie, M. C., Potekhina, I. D. (eds.). Prehistoric Ukraine: From the First Hunters to the First Farmers. Oxford: Oxbow Books, p. 187-233.

Longin, R. 1971. New method of collagen extraction for radiocarbon dating. Nature, 230 (5291), p. 241.

Madden, G. D., Kartsen, J. K., Ledogar, S. H., Scmidt, R., Sokhatsky, M. P. 2018. Violence at Verteba Cave, Ukraine: New insights into the Late Neolithic Intergroup Conflict. International Journal of Osteoarchaeology, 28, p. 44-53.

Mallory, J. P. 1987. Editor's Introduction. In: Telegin, D. Ya., Potekhina, I. D. Neolithic cemeteries and populations in the Dnieper Basin. British Archaeological Reports, International Series, 383. Oxford: BAR Publishing, p. v-ix.

Mathieson, I., Alpaslan-Roodenberg, S., Posth, C., Szécsényi-Nagy, A., Rohland, N., Mallick, S., Olalde, I., Broomandkhoshbacht, N., Candilio, F., Cheronet, O. et al. 2018. The Genomic History of Southeastern Europe. Nature, 555 , p. $197-203$

Minagawa, M., Wada, E. 1984. Stepwise enrichment of ${ }^{15} \mathrm{~N}$ along food chains: further evidence and the relation between $\delta^{15} \mathrm{~N}$ and animal age. Geochimica et cosmochimica acta, 48, 5, p. $1135-1140$

Motuzaitë Matuzevičiǔtë, G., Telizhenko, S. 2016. The first farmers of Ukraine: an archaeobotanical investigation and AMS dating of wheat grains from the Ratniv 2 site. Archeologia Lituana, 17, p. 100-111.

Müldner, G., Richards, M. P. 2005. Fast or feast: reconstructing diet in later medieval England by stable isotope analysis. Journal of Archaeological Science, 32, 1, p. 39-48.

Nikitin, A. G. 2011. Bioarchaeological analysis of Bronze Age human remains from the Podillya Region of Ukraine. Interdisciplinaria Archaeologica: Natural Sciences in Archaeology, 2, 1/201, p. 9-14.

Nikitin, A. G., $\quad$ Sokhatsky, P., Kovaliukh, M. M., Videiko, M. Y. 2010. Comprehensive site chronology and ancient mitochondrial DNA analysis from Verteba Cave - a Trypillian culture site of Eneolithic Ukraine. Interdisciplinaria Archaeologica: Natural Science in Archaeology, 1, 1-2, p. 9-18.

Nikitin, A. G., Potekhina, I. D., Rohland, N., Mallick, S., Reich, D., Lillie, M. C. 2017. Mitochondrial DNA analysis of Eneolithic Trypillians from Ukraine reveals Neolithic farming genetic roots. PLoS ONE, 12, 2, e0172952.

O'Connell, T. C., Levine, M. A., Hedges, R. E. M. 2000. The importance of fish in the diet of central Eurasion peoples from the Mesolithic to the early Iron Age. In: Levine, M. A., Renfrew, A. C., Boyle, K. (eds.). Prehistoric Steppe Adaptation and the Horse. Cambridge: McDonald Institute for Archaeological Research, p. 253-68.
Philippsen, B. 2013. The freshwater reservoir effect in radiocarbon dating. Heritage Science, 1, 1, p. 24.

Potekhina, I., Telegin, D. 1995. On the Dating of the Ukrainian Mesolithic-Neolithic Transition. Current Anthropology, 36, 5, p. 823-826.

Potekhina, I., Lillie, M. C., Budd, C. E. 2014. Analiz paleodiyety za danymy stabilnykh izotopiv u populyatsiyakh epipaleolitu-eneolitu Serednioho ta Nyzhnioho Podniproviya. Istorychna antropolohiya ta bioarkheolohiya Ukrainy, I, s. 5-20.

Potekhina, I. D. 2018. Pokhodzhennya trypiltsiv iz pechery Verteba u svitli kraniolohiyi i arkheohenetyky. Mahisterium. Arkheolohichni studiyi, 70, c. 25-33.

Richards, M. P. 1998. Palaeodietary studies of European human populations using bone stable isotopes. D. Phil. Thesis. University of Oxford.

Richards, M. P. 2002. A brief review of the archaeological evidence for Palaeolithic and Neolithic subsistence. European Journal of Clinical Nutrition, 56, p. 1270-1278.

Sayle, K. L., Hamilton, W. D., Gestsdyttir, H., Cook, G. T. 2016. Modelling Lake Məvatn's freshwater reservoir effect: Utilisation of the statistical program FRUITS to assist in the re-interpretation of radiocarbon dates from a cemetery at Hofstapir, north-east Iceland. Quaternary Geochronology, 36, p. 1-11.

Schulting, R. J., Richards, M. P. 2001. Dating women and becoming farmers: new palaeodietary and AMS evidence from the Breton Mesolithic Cemeteries of Téviec and Нолdic. Journal of Anthropological Archeology, 20, p. 314-344.

Schulting, R. J., Bronk Ramsey, C., Goriunova, O. I., Bazaliiskii, V. I., Weber, A.W. 2014. Analysing radiocarbon reservoir offsets with stable isotope data: a case study using paired human and faunal remains from the Cis-Baikal region, Siberia. Radiocarbon, 56, 3, p. 991-1008.

Schulting, R. J., Bronk Ramsey, C., Bazaliiskii, V. I., Weber A. W. 2015. Highly variable freshwater reservoir offsets found along the Upper Lena watershed, Cis-Baikal, southern Siberia. Radiocarbon, 57, 4, p. 1-13.

Schwarcz, H. P., Schoeninger, M. 1991. Stable isotope analysis in human nutritional ecology. Yearbook of Physical Anthropology, 34, p. 283-321.

Schoeninger, M., DeNiro, M. 1984. Nitrogen and carbon isotopic composition of bone collagen from marine and terrestrial animals. Geochimica et Cosmochimica Acta, 48, p. 625639.

Sealy, J. C., Johnson, M., Richards, M., Nehlich, O. 2014. Comparison of two methods of extracting bone collagen for stable carbon and nitrogen isotope analysis: comparing whole bone demineralization with gelatinization and ultrafiltration. Journal of Archaeological Science, 47, p. 64-69.

Telegin, D. Ya. 1986. Derievka: a settlement and cemetery of Copper Age horse keepers on the middle Dnieper. British Archaeological Report, S287. Oxford: BAR Publishing.

Telegin, D. Ya., 1987. Neolithic cultures of the Ukraine and adjacent areas and their chronology. Journal of World Prehistory, 1 (3), p. 307-331.

Telegin, D. Ya., Potekhina, I. D. 1987. Neolithic cemeteries and populations in the Dnieper Basin. British Archaeological Report, S383. Oxford: BAR Publishing.

Telegin, D. Ya., Titova, E. N. 1993. La Zone des Steppes. In: Kozlowski, J (ed.). Atlas du Néolithique européen. 1: L'Europe orientale. (Études et Recherches Archéologiques de l'Université de Liège, 45. Liège, p. 463-494.

Telegin, D. Ya., Zaliznyak, L. L. 1975. Raskopki na Igren'skom poluostrove. Arkheologicheskiye otkrytiya 1974 g., s. 358-359.

Telegin, D. Ya., Potekhina, I. D., Kovaliukh, M. M., Lillie, M. C. 2000. Chronology of the Mariupol-type cemeteries and the problem of the periodisation of the Neolithic to Copper Age cultures of Ukraine. Radiocarbon \& Archaeology, 1, 1 , p. 59-74.

Telegin, D. Ya., Potekhina, I. D., Lillie, M. C., Kovaliukh, M. M. 2002. The chronology of the mariupol-type cemeteries of Ukraine re-visited. Antiquity, 76, p. 356-363.

Telegin, D. Ya., Lillie, M. C., Potekhina, I. D., Kovaliukh, M. M. 2003. Settlement and economy in Neolithic Ukraine: a new chronology. Antiquity, 77 (279), p. 456-470.

Tieszen, L. L., Fagre, T. 1993. Effect of diet quality and composition on the isotopic composition of respira- 
tory $\mathrm{CO}_{2}$, bone collagen, bioapatite, and soft tissues, In: Lambert, J. B., Grupe, G. (eds.). Prehistoric Human Bone: Archaeology at the Molecular Level. New York: Springer, p. 121155.

Van Klinken, G. J. 1999. Bone collagen quality indicators for palaeodietary and radiocarbon measurements. Journal of Archaeological Science, 26, 6, p. 687-695.

\section{C. Lillie, C. E. Budd}

\section{DIET ISOTOPE ANALYSIS AND RELATED STUDIES IN PREHISTORIC UKRAINE: FACT, FICTION AND FANTASY}

The authors consider scientific studies of Ukrainian skeletal material across the Epipalaeolithic to Eneolithic periods and offer some observations in relation to the efficacy of studies undertaken by different researchers. Firstly, the authors summarize the results of their own research since the original research undertaken by Lillie in the early $1990^{\mathrm{s}}$, and present period based overviews (fig. 1-3) which discuss the nature of the evidence, the fact that fish remains important across the periods studied. The data also highlights the fact that by the Eneolithic period different culture groups are following distinct subsistence strategies. This is obviously marked by western dietary pathways linked to the integration of agro-pastoralism (and associated to presumed Trypillia farming groups at Verteba Cave), and those of the eastern hunter-fisher-foragers in the Dnieper region at Igren VIII and Molukhov Bugor.

Interestingly the chronological separation between these two sites is also linked to dietary variability. At the earlier site of Igren VIII there is diet isotope evidence for a relatively heavy reliance on freshwater resources as ca. $4300-4000 \mathrm{cal} \mathrm{BC}$, whilst at the latter site of Molukhov Bugor, at 3950-3700 cal BC, a reduction in the reliance on freshwater resources is in evidence. This is accompanied by evidence for a broader spectrum approach to the exploitation of the wild resources in and around the Dnieper Rapids region. Radiocarbon dating is shown to be affected by the FRE at the sites in and around the Dnieper system. This is clearly not the case at Verteba Cave because the freshwater reservoir effect is not associated with dietary pathways that place a reliance on terrestrial resources.

The authors discuss the dating (fig. 4-6) and mobility and dietary isotope studies that they undertook at this location and contextualize these by comparison to the work of other researchers. It is suggested that some issues occur in relation to the different research groups activities at Verteba Cave, and the fact that there is a clear need for a more considered approach to the data presented by these other groups is highlighted. It could be argued that a lack of detailed knowledge and collaboration occurs despite the fact that there are clear overlaps between research agendas. The authors conclude with a call for targeted multi-disciplinary analyses aimed at whole cemetery studies in order to further enhance our understanding of socio-economic and societal developments during the early to mid-Holocene in Ukraine.

Keywords: Ukraine, prehistory, dietary isotope analysis, $\delta^{13} \mathrm{C}, \delta^{15} \mathrm{~N}$, AMS dating, freshwater reservoir effects.
М. К. Ліллі, Ч. Е. Бад

\section{ІЗОТОПНИЙ ДІСТНИЙ АНАЛІЗ ТА ПОВ'ЯЗАНІ З НИМ ДОСЛІДЖЕННЯ ПЕРВICHOÏ ICTOРІЇ УКРАЇНI: ФАК- ТИ, ВИГАДКИ ТА ФАНТАСТИКА}

Автори розглядають результати вивчення скелетного матеріалу періоду від епіпалеоліту та енеоліту та наводять деякі спостереження щодо ефективності досліджень, проведених різними вченими. Перш за все, автори узагальнюють результати досліджень, які проводились М. Ліллі з колегами з початку 1990-х рр., та проводять огляд нових результатів (рис. $1-3$ ), які підтверджують той фракт, що риба залишалася важливим продуктом харчування протягом названих періодів. Отримані дані також підкреслюють той фракт, що в епоху енеоліту різні культурні групи дотримувалися різних харчових стратегій. Це, очевидно, визначаеться західними впливами та інтегращією землеробства і скотарства (трипільська фермерська група з печери Вертеба), та традищіями мисливців-рибалок-збирачів з Ігрені VIII та Молюхового Бугра у Подніпров'ї.

Цікаво, що хронологічна відмінність між цими двома пам'ятками супроводжуеться і харчовою мінливістю. На старшій пам'ятці Ігрень VIII отримані ізотопні дані про відносно високу залежність від прісноводних ресурсів у період $4300-4000 \mathrm{cal} \mathrm{BC,} \mathrm{тоді} \mathrm{як} \mathrm{на} \mathrm{піз-}$ нішій пам'ятці Молюхів Бугор, дані свідчать про зменшення залежності від прісноводних ресурсів протягом 3950-3700 cal BC. Ці результати супроводжуються доказами використання більш широкого спектру природних ресурсів у регіоні Дніпровських порогів та навколо нього. Показано також, що на радіовуглецеві дати на пам'ятках у басейні Дніпра впливае прісноводний резервуарний едект. Цього не спостерігається на матеріалах з печери Вертеба, оскільки ефект прісноводного резервуару не пов'язаний 3 діетичними ланцюгами, які залежать від наземних ресурсів.

Отримані авторами результати датування (рис. 46), дослідження мобільності та дієтних ізотопів обговорюються у контексті результатів іншшх дослідників. Висловлюеться припущення, що діяльність різних дослідницьких груп у печері Вертеба породжуе низку проблем, що викликае необхідність продуманішого підходу до даних, представлених іншими групами. Можна стверджувати, що незважаючи на спільну тематику і близькі програми, окремим дослідницьким групам бракуе детальних знань та співпращі. Стаття завершуеться закликом до цілеспрямованого мультидисциплінарного аналізу при дослідженні всіх могильників з метою подалышого вдосконалення нашого розуміння сощіально-економічних та суспільних подій протягом раннього та середнього голоцену на території України.

Ключові слова: Україна, передісторія, аналіз дієтних ізотопів, $\delta^{13} \mathrm{C}, \delta^{15} \mathrm{~N}$, датування AMS, прісноводний резервуарний ефрект.

Одержано 10.07.2020

БАД Челсі, Доктор фрілософрії, Постдокторант університету м. Умеа, SE 901-87, Швеція.

BUDD Chelsea, PhD, Postodcotral Research Fellow, Umeå University, SE 901-87, Sweden.

ORCID: 0000-0001-8527-9669, e-mail: Chelsea.budd@umu.se.

ЛІЛЛІ Малкольм, Доктор філософрії, Профресор університету м. Умеа, SE 901-87, Швеція.

LILLIE Malcolm, PhD, Professor, Umeå University, SE 901-87, Sweden.

ORCID: 0000-0002-6054-3651, e-mail: malcolm.lillie@ umu.se. 